\title{
Mechanisms for the Onset of the African Humid Period and Sahara
}

\section{Greening 14.5-11 ka B.P.*}

OLIVER TIMM ${ }^{\dagger}$ International Pacific Research Center, SOEST, University of Hawai ‘i at Manoa

PETER KÖHLER Alfred Wegener Institute for Polar and Marine Research, D-27515 Bremerhaven, Germany

AXEL TIMMERMANN International Pacific Research Center, SOEST, University of Hawai' $i$ at Manoa

LAURIE MENVIEL International Pacific Research Center, SOEST, University of Hawai 'i at Manoa

${ }^{*}$ This is International Pacific Research Center contribution number 642 and School of Ocean and Earth Science and Technology contribution number XXXX.

${ }^{\dagger}$ Corresponding author address: Dr. Oliver Timm, International Pacific Research Center, SOEST, University of Hawai ‘i at Manoa, POST Bldg. 401, 1680 East West Rd, Honolulu, HI, 96822.

E-mail: timm@hawaii.edu 


\begin{abstract}
The mechanisms leading to the onset of the African Humid Period (AHP) 14,500 to 11,000 years ago are elucidated using two different climate-vegetation models in a suite of transient glacialinterglacial simulations covering the last 21,000 years. A series of sensitivity experiments investigated three key mechanisms (local summer insolation and ice sheet evolution, vegetationalbedo-precipitation feedback, $\mathrm{CO}_{2}$ increase via radiative forcing and fertilization) that control the climate-vegetation history over North Africa during the last glacial termination. The simulations showed that neither orbital forcing nor the remote forcing from the retreating ice-sheets alone were able to trigger the rapid formation of the AHP. Only both forcing factors together can effectively lead to the formation of the AHP. The vegetation-albedo-precipitation feedback enhances the intensity of the monsoon and further accelerates the onset of the AHP. The experiments indicate that orbital forcing and vegetation-albedo-precipitation feedback alone are insufficient to trigger the rapid onset of the AHP. The sensitivity experiments further show that the increasing radiative forcing from rising $\mathrm{CO}_{2}$ concentrations had no significant impact on the temporal evolution of the African monsoon during the last deglaciation. However, the fertilization effect of $\mathrm{CO}_{2}$ is important for the terrestrial carbon storage. The modeling results are discussed and compared with paleo proxy records of the African monsoon system. It is concluded that the model results presented here do not lend support to the notion that simple insolation thresholds govern the abrupt transitions of North African vegetation during the early to middle Holocene.
\end{abstract}




\section{Introduction}

During the last glacial termination and the early Holocene (15-9 ka B.P.), paleoclimate proxy data consistently show a northward extension of grass and low-shrubs into the Sahel/Sahara region (Jolly et al. 1998; Gasse 2000; Prentice and Jolly 2000; Peyron et al. 2006; Garcin et al. 2007) that was accompanied by significant changes of the hydrological conditions over northern Africa (Overpeck et al. 1996; deMenocal et al. 2000; Morrill et al. 2003; Fleitmann et al. 2003; Peck et al. 2004; Shanahan et al. 2006; Weldeab et al. 2007; Fleitmann et al. 2007). While numerous paleoproxy (e.g. deMenocal et al. 2000; Fleitmann et al. 2007; Kröpelin et al. 2008), archaeological (Kuper and Kröpelin 2006) and climate modeling studies (Kutzbach et al. 1996; Kutzbach and Liu 1997; Braconnot et al. 1999, 2007) have explored the enhancement of the monsoon during this so-called African Humid Period (AHP) and its termination around 6-4 ka B.P. (Claussen 1997; Brovkin et al. 1998; Renssen et al. 2003, 2006a; Liu et al. 2006, 2007), the onset mechanism is less understood (deMenocal et al. 2000; Gasse 2000).

The long-term time-evolution of rainfall and vegetation in northern Africa rainfall is governed by the position of the Intertropical Convergence Zone (ITCZ) and its seasonal migration, which constitutes the African monsoon system in this region. Meridional gradients of the diabatic atmospheric forcing provide a strong control on the trade wind strength, its convergence (Gill 1980) and, hence, the meridional position of the ITCZ. On orbital timescales, the precessional cycle induces considerable changes in the seasonally-modulated meridional insolation gradients over the tropics (Timmermann et al. 2007). Periods of increased boreal summer insolation (such as around 11 ka B.P.) thus caused northward shifts of the ITCZ. Moreover, the strength of the trade winds over northern Africa depends on the size of the Eurasian ice-sheet (Justino et al. 2006), on the 
prevailing sea surface temperature (SST) in the tropical and North Atlantic (Xue and Shukla 1998; Zeng et al. 1999; Giannini et al. 2003; Okumura and Xie 2004; Zhang and Delworth 2006) as well as on SST anomalies in the Indian and Pacific Oceans (Bader and Latif 2003; Giannini et al. 2008). Paleoclimate simulations of the mid-Holocene (6 ka B.P.) with atmospheric General Circulation models (GCMs) using prescribed SSTs underestimated the northward shift of the rain belt into the Sahel/Sahara compared with pollen and lake level reconstructions (Joussaume et al. 1999). Coupled GCM simulations show that the effect of air-sea interactions improves the representation of the mid-Holocene monsoon circulation in comparison with paleo-proxy data considerably (Braconnot et al. 2007). Similarly, the coupling with an interactive vegetation model can improve the representation of the northward shift of the ITCZ in the model simulations (Kutzbach et al. 1996; Kutzbach and Liu 1997; Braconnot et al. 1999, 2007).

In contrast to the termination of the AHP around 6-4 ka B.P. in the relatively stable Holocene epoch, the onset of the AHP between 14-11 ka B.P. occurred during a time of major environmental changes. The Laurentide and Scandinavian ice-sheets retreated (Peltier 1994), the Atlantic meridional overturning circulation (AMOC) waxed and waned (McManus et al. 2004), $\mathrm{CO}_{2}$ concentrations increased (Monnin et al. 2001) and boreal summer insolation at $20^{\circ} \mathrm{N}$ intensified (Berger 1978) (see also Fig. 4). It is likely that all of these factors contributed to the meridional movements of the ITCZ between 14-11 ka B.P. and hence to the onset of the AHP.

The movement of the ITCZ on orbital to millennial timescales is not only governed by external forcings, but it can also be affected by internal vegetation-climate feedbacks. An increase in vegetation coverage reduces the regional albedo, leading to warming and increased atmospheric convergence and possibly increased precipitation (Charney 1975; Xue and Shukla 1996; Claussen 1997; Claussen and Gayler 1997; Texier et al. 1997; Broström et al. 1998). Vegetation cover also 
affects the soil moisture and latent heat flux from the ground to the atmosphere by controlling the evapotranspiration (Levis et al. 2004). Another feedback is that the desert sand itself changes its albedo (Levis et al. 2004; Wang et al. 2008). The large-scale atmospheric circulation response to the surface changes in northern Africa influences the SST in the nearby Atlantic. Air-sea interactions provide an effective feedback on the atmospheric circulation and eventually on the vegetation (Braconnot et al. 1999; Ganopolski et al. 1998). Another important governing factor for the terrestrial biosphere in tropical Africa is provided by the $\mathrm{CO}_{2}$ fertilization effect (Friedlingstein et al. 1995; Gill et al. 2002; Köhler and Fischer 2004).

The joint effects of external forcing and internal feedbacks in the coupled vegetation-atmosphereocean system determine the time-evolution of the ITCZ and vegetation in northern Africa. According to paleo-proxy data reconstructions, the Last Glacial Maximum (LGM) climate in this region was arid. Gradual changes in the external forcing factors during Termination $1(\approx 18-12$ ka B.P.) could have led to continuous shifts of the ITCZ. Such long-term shifts could have induced severe droughts in regions outside the cone of influence of the ITCZ and wetter conditions in regions that became part of the seasonal migration area of the ITCZ. While the initial forcing changes and large-scale ITCZ shifts were probably quite continuous, the regional hydrological and vegetation response near the meridional boundaries of the seasonal ITCZ migration could have been highly nonlinear and abrupt. Such type of nonlinear behavior is typical for semi-arid regions that are under the control of the ITCZ such as in the Sahel zone. Another mechanism that could have generated abrupt changes in vegetation coverage in northern Africa was recently described in Liu et al. (2006, 2007). A "stable collapse" of the vegetation can occur without a strong land-surface feedback, if precipitation variability is large on decadal and interdecadal timescales. Furthermore, multiple steady states in the vegetation depend on the numerical implementation of plant functional 
type (PTF) classifications, in particular if the classification is based on empirical or physiological threshold values for certain climate parameters (such as precipitation and temperature). These threshold-dependent vegetation responses can lead to an abrupt atmospheric response in the coupled model, which would further influence the initial change in vegetation (Kleidon et al. 2007). In such systems, multiple equilibria may exist due to the hard thresholds in the PTF classification scheme.

In the light of these multiple forcings, feedbacks and nonlinearities (see schematics in Fig. 1), the existing paleo-proxy data from northern Africa provide important but insufficient information about the climate-vegetation system. Climate-vegetation simulations allow for an additional insight into the mechanisms behind shifts in the monsoon-vegetation system. In fact, transient sensitivity experiments are advantageous for the study of the key processes that can explain the timeevolution of the paleo-proxy records, but simulations from the Last Glacial Maximum (LGM) into the Holocene period have been rarely conducted (Ganopolski et al. 1998; Lunt et al. 2006; Timm and Timmermann 2007; Timmermann et al. 2009; Liu et al. 2009).

Here we investigate the causes of terrestrial vegetation changes over North Africa in a set of transient climate sensitivity experiments that cover the last $21 \mathrm{ka}$. These experiments give an estimate of the individual importance of changes in local summer insolation, ice-sheets and atmospheric $\mathrm{CO}_{2}$ levels for the onset of the AHP. Moreover, the potential role of the vegetation-albedoprecipitation feedback for the AHP is discussed. Because of the rather simple representation of vegetation in one of the used models, feedbacks resulting from changes in soil moisture and evapotranspiration are not addressed in this study. The model simulations are compared with existing paleo-proxy data.

Our modeling study will explore the following hypotheses: 
- H1 Orbital forcing and shrinking Northern Hemispheric ice-sheets trigger the onset of the AHP around 14.5-11 ka B.P.

- H2 The vegetation-albedo-precipitation feedback is accelerating the greening of the Sahara.

- $\mathbf{H 3}$ The concomitant increase in the atmospheric $\mathrm{CO}_{2}$ concentration supports the vegetation expansion.

The paper is organized as follows: In section 2 the models and the specific setups of the sensitivity experiments are described. Section 3 includes a comparison of the control experiment with the present-day African monsoon system. The main results of our model experiments are presented to support the hypotheses H1-H3. Section 4 provides a discussion of the model results and includes model-proxy data comparison for the AHP. We will discuss the validity of the insolation threshold mechanism (deMenocal et al. 2000) and the potential effects of multiple equilibrium states and the consequences of the Younger Dryas for the interpretation of the AHP onset. A brief summary is given in section 5 .

\section{Models and Methods}

To understand the essential causes for the rapid onset of the African monsoon, several simulations with an "Earth System Model of Intermediate Complexity" (EMIC) were conducted. The model LOVECLIM was used in this study to simulate the transient climate and vegetation history under various paleoclimatic forcing scenarios. In order to test the robustness of the LOVECLIM results and to further study some specific aspects of the changes in the vegetation over North Africa

during the onset phase, we made use of the dynamic global vegetation model Lund-Postdam-Jena 
LPJ-DGVM (Sitch et al. 2003) and results from previous time-slice experiments from the HadSM3 model (Kaplan et al. 2002; Joos et al. 2004; Köhler et al. 2005). The paleoclimate simulations are summarized in Table. 1.

\section{a. EMIC-type simulations with LOVECLIM}

A set of sensitivity experiments with different combinations of transient forcings were conducted with LOVECLIM. This version has been used in Renssen et al. (2003, 2005, 2006b,a) to study vegetation-albedo-precipitation feedbacks during the Holocene. The atmospheric component is a global three-layer model with horizontal spherical grid T21 (approximately $5.6^{\circ} \times 5.6^{\circ}$ resolution). The dynamical part is based on the quasi-geostrophic vorticity equation with additional ageostrophic forcing terms included (Opsteegh et al. 1998). The diabatic core is based on the thermodynamic equation that includes diabatic heating from radiation, sensible heat flux and latent heat release. Cloud cover is prescribed in this model according to modern climatological annual cycle. LOVECLIM includes a full hydrological cycle that is closed by a simple soil moisture bucket scheme and river runoff.

The global dynamical vegetation (grassland and forest) model VECODE (Brovkin et al. 1998) is coupled to the atmosphere in a simple way. Precipitation and temperatures are communicated

to the vegetation and surface characteristics in the atmospheric module are modified depending on the vegetation cover. In the current version only the land albedo is changed. Other effects from the vegetation on the soil moisture, runoff, evapotranspiration or surface roughness are not implemented in this model version. Consequently, this model version only allows for the study of albedo-feedbacks. The implications of this specific model constraint for the results will be 
part of the discussion section. Aside from the climatic conditions in form of temperature and precipitation, VECODE implements a logarithmic dependence of net primary production (NPP) on the atmospheric $\mathrm{CO}_{2}$ concentration.

The ocean component (Coupled Large-Scale Ice Ocean, CLIO) is a three dimensional primitive equation model with $3^{\circ} \times 3^{\circ}$ grid resolution and 20 unevenly spaced $\mathrm{z}$ levels in the vertical coordinate (Goosse and Fichefet 1999; Goosse et al. 1999). It includes a fully coupled thermodynamicdynamic sea-ice component. Mixing along isopycnals, parametrization of vertical mixing and convection are comparable to other ocean GCMs. The effect of small-scale eddies is parametrized according to Gent and McWilliams (1990). It must be noted that a flux correction in form of an additional negative (positive) freshwater flux is applied to remove a bias in the freshwater budget over the North Atlantic and Arctic (North Pacific) (Renssen et al. 2002). This corrections has its validity only for present day climate and a systematic evaluation of its effects under glacial conditions or transient states between LGM and present is still an unresolved issue.

We modified the standard LOVECLIM model in order to increase its sensitivity to atmospheric $\mathrm{CO}_{2}$ variations by doubling the sensitivity of the longwave radiation parametrization with respect to $\mathrm{CO}_{2}$ concentrations (Timm and Timmermann 2007). This results in a global equilibrium temperature rise of about $2.5 \mathrm{~K}$ for a rise in $\mathrm{CO}_{2}$ from $280 \mathrm{ppmv}$ to $700 \mathrm{ppmv}$.

LOVECLIM has been part of the recent Paleoclimate Model Intercomarison Project 2 (PMIP2) and its simulation of North African climate for LGM and mid-Holocene is comparable with that of more sophisticated GCMs. 


\section{b. Control experiment}

For the comparison with the present day climate conditions over northwestern Africa we integrated LOVECLIM for 1000 years with present-day orbital configuration, constant preindustrial greenhouse gases $\left(\mathrm{CO}_{2}=277\right.$ ppmv, $\left.\mathrm{CH}_{4}=726 \mathrm{ppbv}, \mathrm{N}_{2} \mathrm{O}=272 \mathrm{ppbv}\right)$ and present-day topography with active vegetation. The last 100 years of the CTR run were averaged and they define the climatological mean control state. The CTR state is compared with the $2 \mathrm{~m}$ air temperatures and $850 \mathrm{hPa}$ winds from ERA-40 reanalysis (Uppala et al. 2005) in order to explore the correspondences and biases between the present climate and the simulation (see Fig. 2,3). The precipitation climatology is compared with the CMAP data (Xie and Arkin 1997). Note that this comparison allows to identify major biases. For this purpose, small discrepancies due to the generally warmer 20th century observations are expected and tolerable.

\section{c. Transient paleosimulations}

Three major forcing factors are prescribed as transient boundary conditions to LOVECLIM: orbital forcing according to Berger (1978), atmospheric $\mathrm{CO}_{2}$ concentrations derived from Antarctic ice cores (Indermühle et al. 1999; Smith et al. 1999), and ice-sheet topography according to Peltier (1994). Further background information on the forcing can be found in Timm and Timmermann (2007) and Timmermann et al. (2009). Other forcing factors related from freshwater input into the Atlantic or Southern Ocean, changes in the dust concentrations, or bathymetry changes were not taken into account. Bering Strait was closed throughout the simulations.

For the simulation of the period from the LGM to the preindustrial conditions, an accelerated forcing scheme was chosen with a factor ten. That is, every tenth year of the original 21,000 year- 
long orbital and $\mathrm{CO}_{2}$ forcing was used to update the boundary conditions of LOVECLIM every single model year. The ice-sheet forcing was updated every hundred years in the model using a 1000 year interval in the ICE4G (Peltier 1994) reconstruction. Details on the accelerated transient simulation technique (Lorenz and Lohmann 2004; Lunt et al. 2006) and the consequences for the phase and amplitude of the climate signal response are discussed in Timm and Timmermann (2007).

Experiment ALL defines the reference run against which the subsequent experiments are compared in order to test the postulated hypotheses of section 1. Changes in the orbital parameters, $\mathrm{CO}_{2}$ and ice-sheets were used to force LOVECLIM over the full 21,000-yr time range. The restart model state is a previously obtained LGM equilibrium climate state. The vegetation module and the vegetation-albedo-precipitation feedback are active.

Sensitivity experiment NOALBFEEDB was forced with the same orbital, $\mathrm{CO}_{2}$ and ice-sheet forcing as in ALL and used the same restart data. The vegetation module was active but the vegetation-albedo-precipitation feedback was suppressed in the following way: present day albedo was prescribed as a boundary condition to the atmosphere, except for the high-latitude regions where ice-sheets forcing determines the albedo. Therefore, vegetation is still dynamically adjusting to the atmospheric conditions but the atmosphere is 'blind' to the resulting albedo changes. The differences between ALL and NOALBFEEDB provide direct insight into the role of the vegetationalbedo-precipitation feedback in northern Africa. This simulation is used to test hypothesis $\mathrm{H} 2$.

ORBONLY is the experiment in which only orbital forcing was transient. $\mathrm{CO}_{2}(190 \mathrm{ppmv})$ and ice-sheet forcing are fixed to LGM conditions throughout the 21,000-yr simulation. Restart data are the same as in ALL. The vegetation-albedo-precipitation feedback was active. This simulation tests whether the direct effect from orbital forcing would have enabled a greening of the Sahara 
if $\mathrm{CO}_{2}$ and ice-sheets had remained in their LGM state. ORBONLY is analysed in order to test hypothesis $\mathrm{H} 1$.

Simulation ICEONLY used transient ice-sheet forcing but orbital and $\mathrm{CO}_{2}$ fixed to LGM conditions. Restart data are the same as in ALL. The vegetation-albedo-precipitation feedback was suppressed as described before for simulation NOALBFEEDB. The difference between this experiment and NOALBFEEDB allow for a quantitative estimate of the importance of the remote ice-sheet forcing on the North African climate. It must be noted that one could have designed a similar experiment with active vegetation-albedo-precipitation feedback. However, the use of present day albedo over North Africa provides a reasonable estimate for the direct remote forcing without additional local feedbacks. ICEONLY gives information for testing hypothesis H1.

CO2ONLY experiment used only $\mathrm{CO}_{2}$ forcing in a transient form, orbital and ice-sheet forcing were kept at LGM conditions. The simulation was only integrated from LGM to 6 ka B.P. Restart data are the same as for experiment ALL. Vegetation-albedo-precipitation feedback was active during the simulation. This experiment gives an estimate for the importance of $\mathrm{CO}_{2}$ for the increasing vegetation and precipitation over North Africa. CO2ONLY is hepful to test hypothesis $\mathrm{H} 1$ and $\mathrm{H} 3$.

Simulation ORBCO2 used transient orbital and $\mathrm{CO}_{2}$ forcing; ice-sheet forcing was kept at LGM conditions. The simulation starts from the same LGM state as ALL. We used this simulation to highlight the importance of both orbital and ice-sheet forcing for the development of the AHP. Therefore, the integration was stopped after the onset-phase at $11 \mathrm{ka} \mathrm{B.P.} \mathrm{ORBCO} 2$ is intented to give additional information on hypothesis $\mathrm{H} 1$. 


\section{d. $L P J-D G V M$}

The dynamic global vegetation model Lund-Potsdam-Jena LPJ-DGVM (Sitch et al. 2003) was used in this study to check the robustness of the results from the EMIC simulation ALL. LPJDGVM here is the updated version including the setting of the Bern Carbon-Cycle Climate model BernCC (Joos et al. 2004; Köhler et al. 2005). However, in our simulations the marine part of the BernCC model was not activated, thus $\mathrm{CO}_{2}$ was prescribed and not internally calculated. For the present study, the light competition scheme in LPJ was updated as described in detail in Strassmann et al. (2008). LPJ-DGVM represents nine PTFs and includes parametrizations of photosynthesis, respiration, fire, growth and competition among the nine PTFs. The distribution of the PTFs is constrained by environmental factors, including climatic factors such as temperature, moisture availability and light. LPJ-DGVM calculates the carbon budget on land in seven categories: leaves, sapwood, heartwood, fine roots, litter and two soil compartments. Decomposition of litter and soil organic matter are temperature and moisture dependent. Fertilization effects through atmospheric $\mathrm{CO}_{2}$ variability is included in the photosynthesis parametrization.

\section{e. Transient paleosimulations with the LPJ-DGVM}

The atmospheric forcing for LPJ-DGVM was obtained from 19 time slice experiments with the HadSM3 model, which is the HadAM3 (Pope et al. 2000) coupled to a slab ocean model and sea-ice model (Hewitt et al. 2001). The atmospheric part has a resolution of $3.75^{\circ} \times 2.5^{\circ}$ with 19 vertical levels. The time slices covered the range from 19-2 ka B.P. in 1000 yr intervals. For every time slice, the model was forced with the corresponding orbital parameters, $\mathrm{CO}_{2}, \mathrm{CH}_{4}$ and ice-sheet reconstructions (ICE4G). Oceanic heat flux convergence was kept at values derived for 
present day conditions. An important feature of these time slice experiments is that HadSM3 was asynchronously coupled with the BIOME4 (Kaplan et al. 2003) equilibrium vegetation model and the land surface conditions within HadSM3 were adjusted accordingly (vegetation type, density, roughness, phenology). Hence, the climate forcing fields from the HadSM3 time slice experiments represent an approximate equilibrium climate with included vegetation-climate feedbacks through albedo and evapotranspiration changes. Anomalies in monthly mean $2 \mathrm{~m}$ air temperatures, precipitation, and cloud cover derived from the time slice experiments were linearly interpolated between the 1000-yr intervals to provide a continuous forcing over the last $21 \mathrm{ka}$ (Kaplan et al. 2002; Joos et al. 2004; Köhler et al. 2005). Temperature anomalies between a preindustrial reference run and simulations of past climates were added to the recent observation-based climatology (Leemans and Cramer 1991) (absolute in temperature, relative otherwise). During the coupling it was necessary to prescribe interannual variations, which are essential to simulate fire in LPJ-DGVM, according to observations by New et al. (2000) (i.e. adding random fluctuations with the standard deviation based on present day climate). This transient simulation over the last 21,000 years with LPJ-DGVM is referred to as LPJALL.

Additional experiments were run with LPJ-DGVM to study the role of the $\mathrm{CO}_{2}$ fertilization on the vegetation and in particular the terrestrial carbon budget over North Africa. For this purpose, two simulations were integrated as described for LPJALL, except for the atmospheric $\mathrm{CO}_{2}$ forcing, that was set to constant concentrations of preindustrial (283 ppmv, LPJF283) and LGM levels (190 ppmv, LPJF190). The results from these sensitivity experiments directly relate to hypothesis H3 from the introduction. 


\section{Results}

As any EMIC-type model, and in contrast to more sophisticated GCMs or regional models, LOVECLIM uses several simplifications in its representation of atmospheric processes. Hence, we will focus on first order climate responses and one specific feedback mechanism in this study. The discussion will then present a more critical evaluation of our results in terms of neglected physical mechanisms, feedbacks and model biases. First, the comparison between LOVECLIM's preindustrial control climate state and observational and reanalysis data is presented. The comparison is concentrating on key features of the North African monsoon system, only. Second, the temporal evolution of the North African climate system is described and compared between the two models (LOVECLIM, HadSM3/LPJ-DGVM) in terms of temperature, precipitation and terrestrial carbon stock. Then, the results are presented according to their relevance for the three different hypotheses.

\section{a. Present-day model performance of the African monsoon}

The monsoon circulation over northwestern Africa is predominantly controlled by the seasonal cycle in the land-sea temperature contrast. The seasonal cycle of the incoming solar radiation is the primary factor for the heating of the land masses. However, tropical air-sea interactions also play an active role in the development of the African monsoon (Xue and Shukla 1998; Okumura and Xie 2004). Since the coarse-resolution atmospheric component of LOVECLIM only uses a parametrization of the ageostrophic circulation terms, it is necessary to test to what extend the coupled model is able to reproduce key elements of the present day monsoon circulation over Africa. 
The preindustrial control simulation (CTR) is compared with the CMAP rainfall data (Xie and Arkin 1997). The meridional migration of the rain belt/ITCZ averaged between $15^{\circ} \mathrm{W}-15^{\circ} \mathrm{E}$ shows a year-round northward position of the ITCZ (Fig. 2). This climatological asymmetry with respect to the equator (Deser et al. 2006; Richter and Xie 2008) is not well captured in LOVECLIM. Further, the model underestimates the rainfall in May. The maximum northward extension is reached in August in the model as well as in the observations. A model-bias towards wetter conditions between $20^{\circ} \mathrm{N}-30^{\circ} \mathrm{N}$ is noticeable.

The annual cycle of $2 \mathrm{~m}$ air temperature anomalies (with respect to the annual mean, averaged between $15^{\circ} \mathrm{W}-15^{\circ} \mathrm{E}$ ) has a similar magnitude in the CTR run and ERA-40 reanalysis data (Uppala et al. 2005) (Fig. 2). The Hovmœller diagram highlights that the seasonal cycle is well reproduced north of $10^{\circ} \mathrm{N}$. Near the equator over the ocean and near coastal regions the model biases are resulting in a weak seasonal temperature cycle. A reduced land-sea contrast is the net result. Similar biases can also be observed in state-of-the-art coupled general circulation models.

A key process for the development and position of the monsoon is the wind response to SST anomalies in the Gulf of Guinea. The simulated meridional wind in 800 hPa shows an underestimation of the southerly wind component (Fig. 3). A reversal to northerly winds is simulated in LOVECLIM (Nov-Mar), whereas the reanalysis data show weak southerly winds (850 hPa level) prevailing over the equator. The modeled zonal winds over the equator indicate that the year-round presence of easterly winds is underestimated [not shown]. The wind bias affects the upwelling and thus contributes to the semi-annual SST cycle in the model. The development of the cold tongue in the eastern equatorial Atlantic, which initially starts with the onset of the southerly winds in May, is suppressed. Furthermore, the bias in the ITCZ position is accompanied by a semi-annual cycle in equatorial SST, whereas observations indicate a dominant annual SST cycle [not shown]. 
The comparison is a reminder that LOVECLIM's abilities are limited with respect to simulating coupled ocean-atmosphere mechanisms of the monsoon system (in fact, state-of-the-art coupled GCMs are hampered by similar biases, such as the missing equatorial cold tongue (Deser et al. 2006; Richter and Xie 2008)). Nonetheless, the model is capable of representing the primary processes that drive the African monsoon: the insolation-driven thermal land-sea contrast and advection of latent heat from the tropical Atlantic into the continent. In the following we will therefore concentrate on the effect of the forcing factors on processes in the atmosphere-vegetation system.

\section{b. Glacial-interglacial evolution of vegetation and climate in North Africa}

In this section the $21 \mathrm{ka}$ time evolution of the prescribed forcing are described and the response of North African monsoon system is investigated through the analysis of temperature, precipitation and vegetation over the Sahel/Sahara zone of North Africa $\left(15^{\circ} \mathrm{N}-30^{\circ} \mathrm{N} / 15^{\circ} \mathrm{W}-35^{\circ} \mathrm{E}\right)$. Since LOVECLIM has a wet bias over North Africa and a limited representation of the monsoon-related air-sea interactions over the tropical Atlantic we compare the LOVECLIM results from simulation ALL with the model LPJ-HadSM3 (simulation LPJALL). Note that we are interested in the principal responses and feedbacks of the climate-vegetation system. Therefore, we are concentrating more on coherent temporal features between these models rather than on their absolute correspondence.

In the experiments with LOVECLIM (and in a similar form in LPJ-HadSM3), three major external forcing factors control the evolution of the climate. (1) The mid-June insolation (Berger 1978) at $20^{\circ} \mathrm{N}$ increased in the early phase of the deglaciation process. Maximum June insolation 
is reached $12 \mathrm{ka} \mathrm{B.P}$ attaining values of up to $490 \mathrm{Wm}^{-2}$. During the Holocene a gradual decline to present day values of $455 \mathrm{Wm}^{-2}$ followed. (2) The prescribed $\mathrm{CO}_{2}$ concentration from the Taylor Dome ice core in Antarctica shows a step-wise increase from 190 to 240 ppmv during 18$16 \mathrm{ka}$ B.P., followed by weak reduction and another 20 ppmv increase from 14-12 ka B.P. Over the Holocene the $\mathrm{CO}_{2}$ continued to rise from 260 to $280 \mathrm{ppmv}$. (3) The prescribed ice volume of the ice-sheets in North America and Europe/Asia (without Greenland) (ICE4G of Peltier (1994)) experienced a sudden drop during 15 and 14 ka B.P. Between 14 and 8 ka B.P. the Laurentide and Eurasian ice-sheets melted entirely and the present-day topography was reached (neglecting the lifting of continents due to the glacial isostatic adjustment). From the temporal characteristics of these forcing factors it could be assumed that the orbital forcing is the most important factor for the generation of the AHP. However, potential contributing factors for the onset of the AHP between 14.5-11 ka B.P. are the drastic reduction in the ice-sheet volume and $30 \mathrm{ppmv} \mathrm{CO}_{2}$ increase.

The experiments with full external forcing and active climate-vegetation feedback (ALL and LPJALL) show coherent temporal evolution of the climate and vegetation over the North African continent (Fig. 5). The $2 \mathrm{~m}$ annual mean air temperatures from ALL and LPJALL cover the same temperature range from the LGM to preindustrial times. The lowest temperatures occur slightly offset in both simulations at 21 ka B.P. and 18 ka B.P. in ALL and LPJALL, respectively. The deglacial warming trend, however starts in both simulations at $18 \mathrm{ka} \mathrm{B.P}$ and ends around $11 \mathrm{ka}$ B.P. Interesting differences in the temperatures are found during the early Holocene, where a local temperature minimum was simulated around $10-8$ ka B.P. in LPJALL. The cause for this cooling in the HadSM3 simulation has not been understood yet. ${ }^{1}$

\footnotetext{
${ }^{1}$ This cooling is not immediately expected from the forcing time series, and it can only be speculated that the local minimum in the $\mathrm{CO}_{2}$ has induced this cool anomaly.
} 
The hydrological conditions over North Africa changed drastically during the last glacial termination (Fig. 5b) from dry conditions to wet conditions in the LGM and the early Holocene, respectively. In both simulations (LPJALL, ALL) the annual mean precipitation marks the onset of the AHP at about 13-12 ka B.P. in LPJALL (40 mm/a in 1000 years) and around 12-10 ka B.P. in the ALL. The magnitude of the change in ALL is about 3 times larger $(120 \mathrm{~mm} / \mathrm{a}$ in 1000 years) than in LPJALL. Precipitation maxima reach about $450 \mathrm{~mm} / \mathrm{a}$ in ALL and $150 \mathrm{~mm} / \mathrm{a}$ in LPJALL. These discrepancies mainly result from the positive precipitation bias in LOVECLIM and amplified by the feedback effects from the positive vegetation-albedo-precipitation feedback. Furthermore, LOVECLIM misses some damping negative vegetation feedbacks (Wang et al. 2008), which can be active in LPJALL due to the more complex representation of vegetation, soil moisture and evapotranspiration. In addition, the lack of ocean dynamics in HadSM3 may result in a biased oceanic feedback to the atmosphere. The slightly delayed increase of the African monsoon intensity in ALL compared with LPJALL is within the expected phase shift resulting from the accelerated forcing in ALL. A typical adjustment time of the vegetation in the coupled climate-vegetation system in LOVECLIM is about 100-200 years (Renssen et al. 2006a), which corresponds to 10002000 years in the accelerated simulation of ALL. On the other hand the asynchronous coupling of HadSM3 with BIOME4, which produced the forcing fields for the LPJALL simulation results in a quasi-instantaneous adjustment to the forcing. One notable difference in the temporal evolution of the African Humid period between both simulations is the pronounced local minimum in the precipitation in correspondence with the temperature minimum in LPJALL. Since this breakdown in the precipitation is not understood in the HadSM3 model, it is difficult to judge what the potential maximum precipitation values could have been in LPJALL during the AHP. Another important difference between the two simulation are observed in the preindustrial precipitation levels. Whereas 
the preindustrial precipitation is higher than during the LGM in LOVECLIM's ALL run, the LGM level is reached during the preindustrial times in LPJALL.

The different precipitation amounts are immediately translated into the total amount of terrestrial carbon summed over North Africa (Fig. 5c). An 'explosive' growth is simulated in ALL leading to a maximum carbon storage of about 45 PgC during the AHP (9-7 ka B.P.). LPJALL only reaches about $10 \mathrm{PgC}$ and the changes with respect to the LGM carbon stock are small. We note, that at the end of the simulation ALL the carbon stock remains above the LGM level; in LPJALL it returns to LGM levels.

In summary, we see that the two different model simulations produce similar temperature changes in response to the forcing in the annual mean, but the the hydrological changes and the associated vegetation changes are different in their absolute values. However, the temporal evolutions from the LGM to the early Holocene and after the AHP are qualitatively the same. With the given discrepancy between precipitation reconstructions and GCM simulations with a general negative model bias (Peyron et al. 2006) and since our focus is on the onset mechanism of the AHP, we believe that the simulations with LOVECLIM provide a good basis to study the initial response phase qualitatively.

c. Hypothesis 1: Orbital forcing and shrinking ice-sheets trigger the onset of the AHP between $14.5-11 \mathrm{ka}$ B.P.

In order to test if orbital forcing alone is sufficient to trigger the onset of the AHP, we performed a sensitivity simulation (ORBONLY), in which the $\mathrm{CO}_{2}$ concentration and the ice-sheets were held fixed at LGM conditions. Only orbital forcing varied with time. As can be seen in Fig. 5, orbitally 
induced insolation anomalies are not sufficient to force a transition from the dry/cool desert climate into a warm/humid climate with flourishing vegetation in Northern Africa. We note that even when we add the time-dependent $\mathrm{CO}_{2}$ forcing to the orbital forcing (experiment ORBCO2) the general warming climate still does not lead to a formation of the AHP. Despite some differences in the annual mean temperatures between ORBONLY and ORBCO2, the $\mathrm{CO}_{2}$ increase has no significant impact on the precipitation/vegetation history. Neither the warming of the atmosphere in response to the 80 ppm increase between 21 ka B.P. and 11 ka B.P., nor the fertilization effect of $\mathrm{CO}_{2}$ on the vegetation growth support the full establishment of the AHP.

From these two simulations it is concluded that ice-sheet forcing must play a crucial role in the formation of the AHP. The difference between ORBONLY and ALL is a measure for the significance of the ice-sheet forcing. The ICE4G ice-sheet topography that was used in our transient simulations shows a rapid retreat of the ice-sheets over North America and Eurasia between 15 and 14 ka B.P. Two teleconnection pathways from the extratropics to the subtropical-tropical region can lead to the suppression of the AHP: (a) major reorganizations of the extra-tropical and subtropical circulation in the Northern Hemisphere in direct response to the retreating ice-sheets and (b) indirectly through changes in the ocean SSTs and air-sea interaction. A systematic analysis of the individual contributions is beyond the scope of this analysis ${ }^{2}$ and we focus on the net effect on the large-scale circulation in the next paragraph.

The retreating ice-sheets lead to a shift in the upper-level wind divergence. In ALL, the $200 \mathrm{hPa}$ velocity potential $\left(\chi_{200}\right)$ indicates divergence over North Africa during the AHP (Fig. 6). In the

\footnotetext{
${ }^{2}$ We tested in separate timeslice experiments the role of Atlantic SST warming from LGM to 9 ka B.P. for the precipitation over North Africa. Roughly it appeared that SSTs contribute in equal parts to the direct ice-sheet related forcing of the Monsoon.
} 
sensitivity experiment with prescribed LGM ice-sheets, this divergent motion is suppressed and partly replaced by convergence. Therefore, it appears that the retreating ice-sheets precondition the atmosphere for convective activity, which itself is affected by the orbitally controlled land heating.

The role of the ice-sheets is only quantified by an indirect approach in the above sensitivity experiment. To test the direct effect of the ice-sheet onto the greening of the Sahara, experiment ICEONLY (only changing ice-sheets) is analyzed. The circulation anomalies induced by the retreating ice sheets lead to an increase in temperature, precipitation and vegetation over North Africa (Fig. 5).

The sensitivity experiments suggest that only the combined effects from orbitally driven insolation changes and the remote effects from ice-sheets can trigger the onset of the AHP. Either forcing alone seems to be insufficient. The strong amplification of the response to orbital forcing is the consequence of changes in the circulation background state caused by the retreating ice-sheets. The comparison of the various sensitivity experiments further suggests that the forcing factors in ALL lead to a nonlinear amplification of the North African monsoon. The relative importance of the individual and combined forcings is summarized in Fig. 7.

The rate of change in precipitation and in terrestrial carbon between $15.5 \mathrm{ka}$ B.P. and $11.5 \mathrm{ka}$ B.P. indicate how ice-sheets, orbital and $\mathrm{CO}_{2}$ forcing in their combined effect amplify the hydrological and vegetative response in a nonlinear way. It must be mentioned that the results depend on the specific choice of the fixed boundary conditions in the sensitivity runs. In NOALBFEEDB with present day albedo, the initial carbon stock increase exceeds the change of ALL because the vegetation-albedo-precipitation feedback in ALL resulted in less vegetation and 'brighter' than present-day albedo over North Africa during the LGM and termination I. Measured from $15.5 \mathrm{ka}$ 
B.P. to the peak of the AHP in ALL at $9.5 \mathrm{ka} \mathrm{B.P.} \mathrm{the} \mathrm{rate} \mathrm{of} \mathrm{change} \mathrm{is} \mathrm{smaller} \mathrm{in} \mathrm{NOALBFEEDB}$ than in ALL.

d. Hypothesis 2: Vegetation-albedo-precipitation feedback is accelerating the greening of the Sahara

This hypothesis is tested with the sensitivity experiment NOALBFEEDB, in which the albedo changes associated with the vegetation are not communicated back to the atmosphere. The differences to the fully coupled experiment ALL show the significance of the vegetation-albedoprecipitation feedback (Fig. 5) for the development of the AHP during the late deglaciation/early Holocene. The albedo changes in ALL promote a northward expansion of the vegetation (Fig. 8) that reaches its maximum at 9 ka B.P. The largest differences in the albedo correspond to differences in the plant fraction between ALL and NOALBFEEDB. They are most pronounced in the central Sahara region located east of $0^{\circ} \mathrm{E}$. The darker surface absorbs more shortwave radiation and leads to a surface warming. Part of the absorbed energy is released into the atmosphere in form of latent heat and increases the local precipitation. The cooling effect from the evaporation buffers the annual mean temperatures. It is due to the latent heat flux that the temperatures are less sensitive to the albedo changes than the precipitation and vegetation cover (Fig. 5). A strong dependence of the precipitation and vegetation on this single feedback mechanism is indicated with about $25 \%$ increase in the annual rainfall amounts between ALL and NOALBFEEDB in the maximum phase of the AHP (10-8 ka B.P.). The result presented here, however, miss other important feedbacks such as cloud-albedo feedback, and the negative feedback from the vegetation on evapotranspiration (Wang et al. 2008), which are not represented in this version of LOVECLIM. Therefore, the 
net effect of the vegetation changes for the formation of the AHP are overestimated in our model.

None of these simulations with vegetation feedback produce a significant plant coverage north of $15^{\circ} \mathrm{N}$ in the western part of the Sahara, where reconstructions from lake level proxies and pollen records indicate a replacement of desert with savanna vegetation. (Jolly et al. 1998; Peyron et al. 2006). The LOVECLIM results are also in conflict with earlier LOVECLIM results modeling the Holocene (Renssen et al. 2003, 2006b,a), where western Sahara was wetter and more vegetated than in our simulation ALL.

A positive vegetation bias in LOVECLIM is found in the central parts of the Sahara. The comparison between the plant fraction coverage of ALL and LPJALL shows that the northward expansion of the vegetation cover is less pronounced in LPJALL at 11 ka B.P. (Fig. 8d). Note that the 9 ka time slice experiment of LPJALL has a reduced plant coverage in the Sahara due to internal variability of the HadSM3 climate state and its subsequent effect on the stability of the AHP in the LPJALL simulation. Parts of the differences between the ALL and LPJALL may thus be related to the transition between multiple equilibrium states in the LPJALL simulation.

As the darker (ALL compared to NOFEEDB) vegetated surface initially warms the surface, the hydrological cycle over North Africa is strengthened with more precipitation and more local evaporation, which is fed by the anomalous moisture flux from the Atlantic during the SW monsoon season. Fig. 9 shows how the vegetation-albedo-precipitation feedback causes a more vigorous monsoon circulation and enhanced moisture transport in NOALBFEEDB and ALL during the AHP. For the region of the central Sahara, the moisture transport by the mean circulation indicates that the bulk of the precipitable water is advected from the southwest. The vegetationinduced anomaly in the moisture flux convergence reaches a maximum over the central Sahara, causing more precipitation in this region. Fig. 9 reveals also some model biases resulting from 
the coarse horizontal and vertical resolution. The topographic barrier of the Central East African Plateau is not adequately resolved in the T21 resolution. Consequently, the low-level jet off Somalia is underestimated (Chakraborty et al. 2002) and the moisture convergence over East Africa overestimated. The eastward transport of moisture over Egypt and the Arabian Peninsula seems to be unreasonably high compared with a recent state-of-the-art-atmosphere-vegetation GCM simulation of Liu et al. (2007) (their figure 3). However, it appears that the moisture transports over central and western parts of North Africa are not strongly affected by this bias.

In our model the strongest effect of the vegetation-albedo-precipitation feedback is located in the interior of the continent. Similarly, the central region of the Sahara was also the most variable region in the Holocene climate transition phase which was simulated with a more complex GCMs (Liu et al. 2007). From the NOALBFEEDB experiment it is concluded that the vegetation-albedoprecipitation feedback over North Africa provides an essential mechanism that accelerated the transition from a glacial state with colder and dryer conditions to the full development of the AHP. The results are presented for the time 9-8 ka B.P., when the vegetation-climate feedback is fully developed. We have performed equivalent analyses for the onset $12-11 \mathrm{ka}$ B.P. and found the same spatial structures but with smaller magnitudes. Our simulations are thus in support of a positive vegetation-albedo-precipiation feedback that was initially proposed by Charney (1975). The involved dynamics in the coupled climate-vegetation system leading to the formation of the AHP are the same mechanisms that were identified as the principal drivers for the termination of the AHP during the mid-Holocene (Kutzbach et al. 1996; Claussen et al. 1999; Renssen et al. 2003, 2006a). However, the feedback is not strong enough to cause a threshold-like transition between two steady states as suggested in Claussen et al. (1999) (see also Liu et al. (2006), Renssen et al. (2006b)). 
e. Hypothesis 3: Increase in the atmospheric $\mathrm{CO}_{2}$ supports the vegetation expansion

We study the effect of increasing atmospheric $\mathrm{CO}_{2}$ concentrations on the terrestrial carbon stock during the last 21,000 years. To isolate the fertilization effect of the increasing $\mathrm{CO}_{2}$ from the climatic forcing factors and feedbacks we analyzed the relationship between carbon stock and precipitation with the LPJ-DGVM model by comparing the experiment LPJALL with two additional sensitivity experiments with fixed $\mathrm{CO}_{2}$ fertilization factor, LPJF190 and LPJF283. Since soil moisture is the limiting climate factor in North Africa, we analyze the North African climate-vegetation state in the precipitation-carbon stock diagram. As can be seen in Fig. 10(a), the vegetation in LPJALL is closely linked to the precipitation through an almost linear relation, as indicated here by the annual precipitation and terrestrial carbon stock. However, the last deglaciation period $(21,000-11,000)$ and the Holocene are offset. For the same precipitation amounts, the Holocene shows about $1 \mathrm{PgC}$ higher carbon stock values. The additional experiments with fixed $\mathrm{CO}_{2}$ show that this offset can be attributed to the fertilization effect. With constant $\mathrm{CO}_{2}$ levels, the systematic differences between the deglacial and Holocene vegetation for a given precipitation regime are significantly reduced. The LPJALL simulation with time-dependent fertilization effect lies between the lower and upper bounds of these sensitivity experiments. In fact, during the Holocene LPJALL and LPJF283 show the same carbon stock levels for the same annual precipitation rates.

A similar two-state behavior is found in the LOVECLIM simulation ALL Fig. 10(b). However, the acceleration technique and the long response time scale of the soil litter distort the results in the LOVECLIM model leading to a more pronounced hysteresis effect. 


\section{Discussion}

The results presented in the previous section suggest that orbital forcing and the retreating ice-sheets are the primary drivers for the rapid onset of the AHP between 14.5-11 ka B.P. The albedo-feedback of the vegetation, which is most pronounced over the central Sahara, accelerates the development of the AHP. In our simulations the climate warming due to increasing $\mathrm{CO}_{2}$ concentrations does not affect the timing and amplitude of the AHP in a significant way. However, the model experiments show that the gradual increase in atmospheric $\mathrm{CO}_{2}$ enhances the vegetation growth through the $\mathrm{CO}_{2}$ fertilization effect.

\section{a. Model dependence of the results}

As we have shown in the comparison of the ALL and LPJALL simulations, significant differences in the amplitudes of the LGM to AHP exist in the two different numerical model types. LOVECLIM's bias towards too high precipitation in the northern part of the Sahara favors the formation of the AHP, vegetation expansion over large parts of the central Sahara and large amounts of terrestrial carbon storage. On the other hand, the simulation of the early to mid-Holocene is apparently too dry in the West Sahara compared with the proxy records (Joussaume et al. 1999; Peyron et al. 2006). At present, it is impossible to judge how strong the biases in the models compromise the response to the forcing or the internal feedbacks. It would therefore be important to conduct similar simulations with more sophisticated coupled ocean-atmosphere-vegetation models.

It is of particular interest that none of the simulations presented here reproduced the rapid termination of the AHP at 6-5 ka B.P. of Claussen et al. (1999). The gradual transition scenario 
discussed here is also distinct from the recent simulations conducted with the FOAM-LPJ climatevegetation model of Liu et al. (2006, 2007). Although they find a gradual rainfall decrease, vegetation changes are abrupt. Our findings are different to the interpretation of the modeling results of Brovkin et al. (1998) and Claussen et al. (1999), who proposed that during the end of the AHP the climate-vegetation system abruptly switched to a stable desert state. Their interpretation requires the existence of multiple equilibrium states in the African climate-vegetation system. The transient paleoclimate simulation of the Holocene by Renssen et al. (2003) and Renssen et al. (2006a) are different in their regional development of the AHP compared to the ALL simulation of this study. In Renssen et al. (2006a) the largest changes in precipitation and vegetation are in the West Sahara not the central Sahara as in simulation ALL. Moreover, the interpretation of the transition from the AHP into the desert state after 6 ka B.P. is interpreted in a different way by Renssen et al. (2006a). They argue that the dynamics of the North African Monsoon system is characterized by a bifurcation point. For summer insolation above a critical level the system has one steady state (green Sahara). As insolation reaches the threshold level two steady states emerge around 6 ka B.P. (green Sahara, desert Sahara). Interannual to centennial variability was high during that time. After 6 ka B.P., the system eventually falls into a single steady-state regime (desert) after further insolation decline. We have not analyzed the role of the interannual to centennial timescale variability during the Holocene, but the gradual decline during the Holocene in simulation ALL is not indicative of a transition between two steady states. Furthermore, the rapid onset is explained by the combined forces from insolation and ice-sheets. We note that the atmospheric conditions from the LPJALL with the partial breakdown of the AHP at 9 ka B.P. (see Fig. 5) could be due to multiple equilibrium states in the HadSM3-BIOME4 simulations. However, the underlying dynamics of potential multiple states have yet to be understood. 
The sensitivity experiments allowed us to investigate the importance of the individual forcing factors. It was found that the climate sensitivity to orbital forcing strongly depends on the mean climate state in the presence of LGM ice-sheets. In other words, the concomitant changes in icesheets amplify the orbital forcing in a nonlinear way. With the current version of LOVECLIM, this result must be considered with some caution. The stationary wave trains radiating from the polar ice-sheets southward to the subtropical region during the boreal summer season are likely to be model-dependent. More complex numerical models must show if the suppressed sensitivity to summer insolation in the presence of European and North American ice-sheets is realistic. It is interesting to compare this with the results from Masson et al. (2000), who were able to simulate a green Sahara state during the phase of northern hemispheric glaciation in MIS 6.5 (175 ka B.P.). Stronger precessional forcing compared with 11 ka B.P. due to higher eccentricity and smaller icesheets compared to the LGM may explain why intensified monsoons can be simulated and explain the proxy records (deMenocal et al. 1993). Nonetheless, we conjecture that the rapid melting of the Northern Hemispheric ice-sheets coinciding with the Bølling-Ållerød (Bard et al. 1990; Peltier 1994; Rohling et al. 2004; Peltier 2005) has delayed the onset of the AHP to the time zone of the BA and thereafter. Paleo-proxy data generally support the notion of a wet and green Sahara during the BA chronozone (Gasse and van Campo 1994; Severinghaus and Brook 1999); and the latest high-resolution proxies confirm the timing (Tjallingii et al. 2008).

The initial development of the green Sahara state was accelerated by the vegetation-albedoprecipitation feedback. The effectiveness of this feedback depends on the contrast between the dry desert sand and vegetation. The difference between the bright desert sand (albedo 0.30-0.35) and the vegetation (albedo 0.26-0.30) during the AHP adds a substantial amount of heat to the surface heat budget during the summer months. Given a clear sky downward shortwave radiation flux of 
$300-400 \mathrm{Wm}^{-2}$ in June (as derived in NCEP reanalysis data for present day, for example), albedo differences of 0.05 result in an extra surface energy supply of $\approx 15-20 \mathrm{Wm}^{-2}$. Other studies have questioned the importance of the albedo feedback because of either small differences between wet desert sand and vegetation and negative vegetation-evapotranspiration feedback (Liu et al. 2007; Notaro et al. 2008; Wang et al. 2008). Wang et al. (2008) argue further that the gradual decline simulated with their models during the Holocene is indicative of an overall negative feedback from the vegetation. Earlier theoretical studies by (Zeng et al. 2002) however support an overall positive feedback between vegetation and precipitation. Here we submit the conjecture that the feedback strength and sign depend crucially on the timescale. How the feedback results from the much shorter timescales translate to the orbital timescales is still not fully understood. The study of Patricola and Cook (2008) on the other hand demonstrated that a strong positive feedback from the vegetation to precipitation exists over the Sahel-Sahara region, but primarily caused by the influence of vegetation on soil moisture and subsequently the strength and position of the African easterly jet.

These aspects cannot be addressed in the current study due to the models physical parametrization and the coarse resolution, respectively. Which of the feedbacks and internal climate processes were eventually responsible for the formation the AHP will require a hierarchy of numerical simulations with different complexities. Nonetheless, for many paleoclimatic interpretations of proxy data, model results from EMICs such as LOVECLIM are suitable. Current insight into African monsoon proxies are still lacking a comprehensive understanding of their response to climate conditions. Without detailed information from paleoclimate proxies, we lack the scientific ability to rigorously test hypothesis and to cross-validate the model results with existing proxies. 


\section{b. Proxy interpretation}

The abruptness of the monsoon changes and its attribution to orbital insolation changes or North Atlantic climate has been discussed on the basis of paleo-proxies (Sirocko et al. 1996; deMenocal et al. 2000; Gasse 2000; Morrill et al. 2003; Adkins et al. 2006; Fleitmann et al. 2007; Shanahan et al. 2006, e.g.). The recent discussion on the rapid intensification of the African monsoon during the last deglaciation showed that the forcing factors (ice-sheets, greenhouse gases, and orbital) as well as extratropical-tropical connections between the North Atlantic or the Southern Ocean and the North African climate are potential control factors that can steer the onset of the AHP. Since it is virtually impossible to separate the forcing factors with individual proxy time series, the presented model results help to re-interpret Monsoon proxy records.

Two prominent marine sediment records off the western coast of Africa, ODP108_658C (deMenocal et al. 2000; Adkins et al. 2006) and MD03_2707 (Weldeab et al. 2007) and the sediment records from Lake Bosumtwi (Peck et al. 2004; Shanahan et al. 2006) show rapid transitions during the Bølling-Ållerød/Younger Dryastransition. The time series are shown in Fig. 11. When plotted against the incoming solar radiation in June at $20^{\circ} \mathrm{N}$, only the terrigenous percent of ODP108_658C exhibits the characteristics of a threshold response. The clustering of the terrigenous percent shows two plateaus. The AHP with incoming insolation above $470 \mathrm{Wm}^{-2}$ is associated with low terrigenous percent values of 40-45\% (green dots in Fig. 11(d)). Clearly separated are the LGM and late Holocene points (in Fig. 11(d)) blue and black points, respectively). The internal dynamics associated with the Younger Dryas can also be distinguished (cyan points in Fig. 11(d)). This scatter diagram can be interpreted to support the hypothesis of monsoon threshold-response to the summer insolation. 
The time series of sea surface salinity (SSS) reconstruction from the Gulf of Guinea (Fig. 11(b)) shows similar abrupt changes to wetter (less saline) conditions around 14.5 ka B.P. and 11.5 ka B.P. An objective identification of a constantly wet AHP is more difficult than in the previous example. The scatter diagram shows no clear threshold level. Instead, the salinity reconstruction has two distinct values for a given insolation level. We interpret these two distinct states as an indicator for the remote forcing from the polar ice-sheets or a tropical response to $\mathrm{CO}_{2}$ changes. Furthermore, our simulation results indicate an additional contribution by the $\mathrm{CO}_{2}$ fertilization effect. A similar behavior is recorded in the percentage of organic material in the Bosumtwi sediment core (Fig. 11(c,f)).

Despite the general correspondence of their temporal features, the projection of the three proxy time series onto a single forcing parameter like summer insolation suggests two very distinct responses of the African monsoon and the Saharan vegetation. One explanation could be the different response functions of the proxies. It has been suggested (Liu et al. 2007) that the response function itself, which links the African monsoon climate and vegetation with the terrigenous percent of ODP108_658C, has a non-linear threshold characteristic. A linear climate change in response to orbital forcing (as suggested by the model results of Liu et al. (2007)) would appear non-linear in the proxy. Preliminary results from new core samples off the coast West Africa (Cole et al. 2008) bear less resemblance with a threshold-response. However, a more detailed analysis must clarify the response function of the aeolian dust records in the sediments.

Presently, the idea of a monsoonal threshold response can be tested with longer records that cover several precession and obliquity cycles. Modeling evidence (Kutzbach et al. 2008; Tjallingii et al. 2008; Braconnot et al. 2008) reveal dominant precession signals over the last 100,000 200,000 years. We used existing records of longer Paleo-monsoon histories from the Dongge Cave 
(Yuan et al. 2004; Kelly et al. 2006) and Hulu Cave (Wang et al. 2001). Only the Dongge Cave proxy provides a weak support for of an insolation threshold [not shown].

\section{c. Forcing from the Atlantic Meridional Overturning Circulation}

Changes in the strength of the AMOC (McManus et al. 2004) have a significant impact on the position of the ITCZ (Timmermann et al. 2007; Stouffer et al. 2006; Menviel et al. 2008; Chang et al. 2008; Mulitza et al. 2008). North West Africa is strongly influenced by associated ocean-atmosphere changes. Millennial-scale changes in the African monsoon-vegetation system changes have been found in paleo-proxies (Tjallingii et al. 2008; deMenocal 2008). The reduction of the AMOC during Heinrich 1 ( e.g. 17-15 ka B.P. according to (McManus et al. 2004)) and the Younger Dryas (about 13-11 ka B.P.) shifted the ITCZ southward. Between these events, the AMOC recovered during the BA and led to a northward shift of the ITCZ and consequently an increase in vegetation. The consequences of the Younger Dryas on the northward expanding vegetation must have been drastic according to the proxy records (Fig. 11) and recent water-hosing experiments (Obata 2007; Mulitza et al. 2008; Menviel et al. 2008). For example, a shutdown of the AMOC in the preindustrial water-hosing experiment of Menviel et al. (2008) resulted in a southward extension of the desert and a $15 \mathrm{PgC}$ carbon loss in the terrestrial carbon stock over North Africa. Regarding the rapid onset of the AHP, this millennial-scale transition from Younger Dryas to pre-boreal climates had further enhanced the rapid onset of the AHP at the beginning of the Holocene. 


\section{Conclusions}

Based on the modeling experiments and the comparison with high-resolution proxy data we conclude that the North African monsoon and the vegetation are sensitive to orbitally driven changes in local insolation and ice-sheets in the Northern Hemisphere. The presence of large ice-sheets can suppress the convection over North Africa and reduce the response to orbital forcing. It is therefore the combined effects from local insolation increase and concomitant melting of northern ice-sheets that causes a sudden greening of the Sahara between 14.5-11 ka B.P. in our model simulations. The contrast in desert and grassland albedo provides an effective positive feedback in the climate-vegetation system. This feedback is responsible for a further intensification of the AHP and contributes to the relatively fast onset of the AHP between 14.5-11 ka B.P . Changes in $\mathrm{CO}_{2}$ concentrations over the last 21,000 years had only a small effect on the vegetation through the $\mathrm{CO}_{2}$ fertilization effect. The modeling results presented here do not lend support to the notion of an insolation threshold governing the abrupt vegetation transitions over North Africa. Future work with more complex coupled ocean-atmosphere-vegetation GCM models (Liu et al. 2009) could help to lend further credence to our postulated hypotheses. So far, our study supports

the hypothesis of the co-forcing from ice-sheets and insolation during the Pliocene-Pleistocene, as postulated in the studies of deMenocal et al. (1993); deMenocal and Rind (1993); deMenocal (1995).

Acknowledgments.

O. Timm, A. Timmermann, L. Menviel are supported by the Japan Agency for Marine-Earth Science and Technology (JAMSTEC) through its sponsorship of the International Pacific Research 
Center. We thank F. Joos for providing the LPJ model and K. Strassmann for implementation of the light competition scheme in LPJ. P. Valdes is thanked for making the HadSM3 available. We thank the reviewers for their valuable comments. This research project received support from the NSF Paleoclimate Program ATM 0712690.

\section{REFERENCES}

Adkins, J., P. deMenocal, and G. Eshel, 2006: The "African humid period" and the record of marine upwelling from excess 230Th in Ocean Drilling Program Hole 658C. Paleoceanography, 21, PA4203, doi:10.1029/2005PA001200.

Bader, J. and M. Latif, 2003: The impact of decadal-scale Indian Ocean sea surface temperature anomalies on Sahelian rainfall and the North Atlantic Oscillation. Geophys. Res. Lett., 30 (22), 2169, doi:10.1029/2003GL018426.

Bard, E., B. Hamelin, and R. G. Fairbanks, 1990: U/Th ages obtained by mass spectrometry in corals from Barbados: Sea level during the past 130,000 years. Nature, 346, 456-458, doi: $10.1038 / 346456 \mathrm{a} 0$.

Berger, A. L., 1978: Long-term variations of daily insolation and Quaternary climatic changes. J. Atmos. Sci., 35 (12), 2 362-2 367, doi:10.1175/1520-0469(1978)035〈2362:LTVODI $\rangle 2.0 . C O ; 2$.

Braconnot, P., S. Joussaume, O. Marti, and N. de Noblet, 1999: Synergistic feedbacks from ocean 
and vegetation on the African monsoon response to mid-Holocene insolation. Geophys. Res. Lett., 26 (16), $2481-2484$.

Braconnot, P., C. Marzin, L. Grégoire, E. Mosquet, and O. Marti, 2008: Monsoon response to changes in Earth's orbital parameters: Comparisons between simulations of the Eemian and of the Holocene. Climate of the Past, 4 (4), 281-294, URL http: / /www . clim-past . net / $4 / 281 / 2008 /$.

Braconnot, P., et al., 2007: Results of PMIP2 coupled simulations of the Mid-Holocene and Last Glacial Maximum - Part 2: Feedbacks with emphasis on the location of the ITCZ and mid- and high latitudes heat budget. Climate of the Past, 3 (2), 279-296, URL http: //www.clim-past. net/3/279/2007/.

Broström, A., M. Coe, S. P. Harrison, R. Gallimore, J. E. Kutzbach, J. Foley, I. C. Prentice, and P. Behling, 1998: Land surface feedbacks and palaeomonsoons in northern Africa. Geophys. Res. Lett., 25 (19), 3615 - 3618.

Brovkin, V., M. Claussen, V. Petoukhov, and A. Ganopolski, 1998: On the stability of the atmosphere-vegetation system in the Sahara/Sahel region. J. Geophys. Res., 103 (D24), 31613 $-31624$.

Chakraborty, A., R. S. Nanjundiah, and J. Srinivasan, 2002: Role of Asian and African orography in Indian summer monsoon. Geophys. Res. Lett., 29 (20), 1989, doi:10.1029/2002GL015522.

Chang, P., et al., 2008: Oceanic link between abrupt changes in the North Atlantic Ocean and the African monsoon. Nature Geosc., 1, 444-448, doi:10.1038/ngeo218. 
Charney, J. G., 1975: Dynamics of deserts and draught in Sahel. Quart. J. Roy. Meteor. Soc., 101 (428), 193-202, doi:10.1002/qj.49710142802.

Claussen, M., 1997: Modeling bio-geophysical feedback in the African and Indian monsoon region. Climate Dynamics, 13 (4), 247 - 257, doi:10.1007/s003820050164.

Claussen, M. and V. Gayler, 1997: The greening of the Sahara during the mid-Holocene: Results of an interactive atmosphere-biome model. Global Ecology and Biogeography Letters, 6 (5), $369-377$.

Claussen, M., C. Kubatzki, V. Brovkin, A. Ganopolski, P. Hoelzmann, and H.-J. Pachur, 1999: Simulation of an abrupt change in Saharan vegetation in the mid-Holocene. Geophys. Res. Lett., 26 (14), 2 037-2 040, doi:10.1029/1999GL900494.

Cole, J. M., P. B. deMenocal, S. L. Goldstein, S. R. Hemming, F. E. Grousset, T. I. Eglinton, and T. Wagner, 2008: An oceanic perspective on the African Humid Period. Eos Trans. AGU, 89(53), Fall Meet. Suppl., Abstract PP23B-1474 INVITED.

deMenocal, P., 2008: Palaeoclimate: Africa on the edge. Nature Geosci., 1, 650-651, doi:10.1038/ ngeo323.

deMenocal, P., J. Ortiz, T. Guilderson, J. Adkins, M. Sarnthein, L. Baker, and M. Yarusinsky, 2000: Abrupt onset and termination of the African Humid Period: Rapid climate responses to gradual insolation forcing. Quat. Sci. Rev., 19 (1-5), 347-361, doi:10.1016/S0277-3791(99)00081-5.

deMenocal, P. B., 1995: Plio-Pleistocene African climate. Science, 270 (5233), 53-59, doi:10. 1126/science.270.5233.53. 
deMenocal, P. B. and D. Rind, 1993: Sensitivity of Asian and African climate to variations in seasonal insolation, glacial ice cover, sea surface temperature, and Asian orography. J. Geophys. Res., 98 (D4), $7265-7287$.

deMenocal, P. B., W. F. Ruddiman, and E. M. Pokras, 1993: Influences of high- and low-latitude processes on African terrestrial climate: Pleistocene eolian records from equatorial Atlantic Ocean Drilling Program site 663. Paleoceanography, 8 (2), 209-242.

Deser, C., A. Capotondi, R. Saravanan, and A. S. Phillips, 2006: Tropical Pacific and Atlantic climate variability in CCSM3. J. Climate, 19, 2451-2 481, doi:10.1175/JCLI3759.1.

Fleitmann, D., S. J. Burns, M. Mudelsee, U. Neff, J. Kramers, A. Mangini, and A. Matter, 2003: Holocene forcing of the Indian monsoon recorded in a stalagmite from Southern Oman. Science, 300 (5626), 1737 - 1739, doi:10.1126/science.1083130.

Fleitmann, D., et al., 2007: Holocene ITCZ and Indian monsoon dynamics recorded in stalagmites from Oman and Yemen (Socotra). Quat. Sci. Rev., 26 (1-2), 170 - 188, doi:10.1016/j.quascirev. 2006.04.012.

Friedlingstein, P., I. Fung, E. Holland, J. John, G. Brasseur, D. Erickson, and S. D., 1995: On the contribution of $\mathrm{CO}_{2}$ fertilization to the missing biospheric sink. Global Biogeochem. Cycles, $9(4), 541-556$.

Ganopolski, A., S. Rahmsdorf, P. V., and M. Claussen, 1998: Simulation of modern and glacial climates with a coupled model of intermediate complexity. Nature, 391, 351-356.

Garcin, Y., A. Vincens, D. Williamson, G. Buchet, and J. Guiot, 2007: Abrupt resumption of the 
African Monsoon at the Younger Dryas-Holocene climatic transition. Quat. Sci. Rev., 26 (5-6), 690 - 704, doi:10.1016/j.quascirev.2006.10.014.

Gasse, F., 2000: Hydrological changes in the African tropics since the Last Glacial Maximum. Quat. Sci. Rev., 19 (1-5), 189-211, doi:10.1016/S0277-3791(99)00061-X.

Gasse, F. and E. van Campo, 1994: Abrupt postglacial climate events in west Asia and NorthAfrica monsoon domains. Earth Planet. Sci. Lett., 126 (4), 435 - 456.

Gent, P. R. and J. C. McWilliams, 1990: Isopycnal mixing in ocean circulation models. J. Phys. Oceanogr., 20 (1), 150-155, doi:10.1175/1520-0485(1990)020<0150:IMIOCM $\rangle 2.0 . C O ; 2$.

Giannini, A., M. Biasutti, and M. M. Verstraete, 2008: A climate model-based review of drought in the Sahel: Desertification, the re-greening and climate change. Glob. Planet. Change, 64 (3-4), 119-128, doi:10.1016/j.gloplacha.2008.05.004.

Giannini, A., R. Saravanan, and P. Chang, 2003: Oceanic forcing of Sahel rainfall on interannual to interdecadal time scales. Science, 302 (5647), 1027 - 1030, doi:10.1126/science.1089357.

Gill, A. E., 1980: Some simple solutions for heat-induced tropical circulation. Quart. J. Roy. Meteor. Soc., 106, 447-462.

Gill, R. A., H. W. Polley, H. B. Johnson, L. J. Anderson, H. Maherali, and R. B. Jackson, 2002: Nonlinear grassland responses to past and future atmospheric $\mathrm{CO}_{2}$. Nature, 417, 279-282, doi: 10.1038/417279a.

Goosse, H., E. Deleersnijder, T. Fichefet, and E. M. H., 1999: Sensitivity of a global coupled 
ocean-sea ice model to the parameterization of vertical mixing. J. Geophys. Res., 104 (C6), $13681-13695$.

Goosse, H. and T. Fichefet, 1999: Importance of ice-ocean interactions for the global ocean circulation: A model study. J. Geophys. Res., 104 (C10), 23 337-23 355, doi:10.1029/1999JC900215.

Hewitt, C. D., C. A. Senior, and J. F. B. Mitchell, 2001: The impact of dynamic sea-ice on the climatology and climate sensitivity of a GCM: A study of past, present, and future climates. Climate Dynamics, 17, 655-668, doi:10.1007/s003820000140.

Indermühle, A., et al., 1999: Holocene carbon-cycle dynamics based on $\mathrm{CO}_{2}$ trapped in ice at Taylor Dome, Antarctica. Nature, 398 (6723), 121-126, doi:10.1038/18158.

Jolly, D., S. P. Harrison, B. Damnati, and R. Bonnefille, 1998: Simulated climate and biomes of Africa during the late Quaternary: Comparison with pollen and lake status data. Quat. Sci. Rev., 17 (6-7), 629-657, doi:10.1016/S0277-3791(98)00015-8.

Joos, F., S. Gerber, I. C. Prentice, B. L. Otto-Bliesner, and P. J. Valdes, 2004: Transient simulations of holocenic atmospheric carbon dioxide and terrestrial carbon since the last glacial maximum. Glob. Biogeochem. Cycl., 18, GB2002, doi:10.1029/2003GB002156.

Joussaume, S., et al., 1999: Monsoon changes for 6000 years ago: Results of 18 simulations from the paleoclimate modeling intercomparison project (PMIP). Geophys. Res. Lett., 26 (7), 859 862, doi:10.1029/1999GL900126.

Justino, F., A. Timmermann, U. Merkel, and W. R. Peltier, 2006: An initial intercomparison of atmospheric and oceanic climatology for the ICE-5G and ICE-4G models of LGM paleotopography. J. Climate, 19 (1), 3-14, doi:10.1175/JCLI3603.1. 
Kaplan, J. O., I. C. Prencite, W. Knorr, and P. J. Valdes, 2002: Modeling the dynamics of terrestrial carbon storage since the Last Glacial Maximum. Geophys. Res. Lett., 29 (22), 2074, doi:10. 1029/2001GL013366.

Kaplan, J. O., et al., 2003: Climate change and Arctic ecosystems: 2. modeling, paleodatamodel comparisons, and future projections. J. Geophys. Res., 108 (D8), 8171, doi:10.1029/ 2002JD002559.

Kelly, M. J., R. L. Edwards, H. Cheng, D. Yuan, Y. Cai, M. Zhang, Y. Lin, and Z. An, 2006: High resolution characterization of the Asian Monsoon between 146,000 and 99,000 years B.P. from Dongge Cave, China and global correlation of events surrounding Termination II. Palaeogeography, Palaeoclimatology, Palaeoecology, 236 (1-2), 20-38.

Kleidon, A., K. Fraedrich, and C. Low, 2007: Multiple steady-states in the terrestrial atmospherebiosphere. Biogeosciences, 4 (5), 707 - 714.

Köhler, P. and H. Fischer, 2004: Simulating changes in the terrestrial biosphere during the last glacial/interglacial transition. Glob. Planet. Change, 43 (1-2), 33-55, doi:10.1016/j.gloplacha. 2004.02.005.

Köhler, P., F. Joos, S. Gerber, and R. Knutti, 2005: Simulated changes in vegetation distribution, land carbon storage, and atmospheric $\mathrm{CO}_{2}$ in response to a collapse of the North Atlantic thermohaline circulation. Climate Dynamics, 25 (7-8), 689-708, doi:10.1007/s00382-005-0058-8.

Kröpelin, S., et al., 2008: Climate-driven ecosystem succession in the Sahara: The past 6000 years. Science, 320 (5877), 765 - 768, doi:10.1126/science. 1154913. 
Kuper, R. and S. Kröpelin, 2006: Climate-controlled Holocene occupation in the Sahara: Motor of Africa's evolution. Science, 313 (5788), 803 - 807, doi:10.1126/science.1130989.

Kutzbach, J. E., G. Bonan, J. Foley, and S. P. Harrison, 1996: Vegetation and soil feedbacks on the response of the African monsoon to orbital forcing in the early to middle Holocene. Nature, 384 (6610), 623 - 626, doi:10.1038/384623a0.

Kutzbach, J. E., X. Liu, L. Z., and G. Chen, 2008: Simulation of the evolutionary response of global summer monsoons to orbital forcing over the past 280,000 years. Climate Dynamics, 30 (6), 567-579, doi:10.1007/s00382-007-0308-z.

Kutzbach, J. E. and Z. Liu, 1997: Response of the African Monsoon to orbital forcing and ocean feedbacks in the middle Holocene. Science, 278, 440-443, doi:10.1126/science.278.5337.440.

Leemans, R. and W. P. Cramer, 1991: The IIASA Climate Database for Land Areas on a Grid with 0.5 Resolution, Research Reports, Vol. RR-91-18. International Institute for Applied Systmes Analysis, Laxenburg, Austria.

Levis, S., G. B. Bonan, and C. Bonfils, 2004: Soil feedback drives the mid-Holocene North African monsoon northward in fully coupled CCSM2 simulations with a dynamic vegetation model. Climate Dynamics, 23 (7-8), 791-802, doi:10.1007/s00382-004-0477-y.

Liu, Z., et al., 2007: Simulating the transient evolution and abrupt change of Northern Africa atmosphere-ocean-terrestrial ecosystem in the Holocene. Quat. Sci. Rev., 26 (13-14), 1818 1837, doi:10.1016/j.quascirev.2007.03.002.

Liu, Z., et al., 2009: Transient simulation of last deglaciation with a new mechanism for BøllingAllerød warming. Science, 325, 310-314, doi:10.1126/science.1171041. 
Liu, Z. Y., Y. Wang, R. Gallimore, M. Notaro, and I. C. Prentice, 2006: On the cause of abrupt vegetation collapse in North Africa during the Holocene: Climate variability vs. vegetation feedback. Geophys. Res. Lett., 33 (22), L22709, doi:10.1029/2006GL028062.

Lorenz, S. J. and G. Lohmann, 2004: Acceleration technique for Milankovitch type forcing in a coupled atmosphere-ocean circulation model: Method and application for the Holocene. Clim. Dyn., 23 (7-8), 727 - 743, doi:10.1007/s00382-004-0469-y.

Lunt, D. J., M. S. Williamson, P. J. Valdes, and T. M. Lenton, 2006: Comparing transient, accelerated, and equilibrium simulations of the last 30000 years with the GENIE-1 model. Clim. Past., $2(2), 221-235$.

Masson, V., P. Braconnot, J. Jouzel, N. de Noblet, R. Cheddadi, and O. Marchal, 2000: Simulation of intense monsoons under glacial conditions. Geophys. Res. Lett., 27 (12), 1747-1 750.

McManus, J. F., R. Francois, J.-M. Gherardi, L. D. Keigwin, and S. Brown-Leger, 2004: Collapse and rapid resumption of Atlantic meridional circulation linked to deglacial climate changes. Nature, 428, 834-837, doi:10.1038/nature02494.

Menviel, L., A. Timmermann, A. Mouchet, and O. Timm, 2008: Meridional reorganizations of marine and terrestrial productivity during Heinrich events. Paleoceanography, 23, PA1203, doi: 10.1029/2007PA001445.

Monnin, E., A. Indermühle, A. Dällenbach, J. Flückiger, B. Stauffer, T. F. Stocker, D. Raynaud, and J.-M. Barnola, 2001: Atmospheric $\mathrm{CO}_{2}$ concentrations over the last glacial termination. Science, 291, 112-114. 
Morrill, C., J. T. Overpeck, and J. E. Cole, 2003: A synthesis of abrupt changes in the Asian summer monsoon since the last deglaciation. Holocene, 13 (4), 465 - 476, doi:10.1191/ $0959683603 \mathrm{hl} 639 \mathrm{ft}$.

Mulitza, S., et al., 2008: Sahel megadroughts triggered by glacial slowdowns of Atlantic meridional overturning. Paleoceanography, 23, PA4206, doi:10.1029/2008PA001637.

New, M., M. Hulme, and P. Jones, 2000: Representing twentieth-century space-time climate variability: Development of 1901-95 monthly grids of terrestrial surface climate. J. Climate, 13 (13), 2 217-2 238, doi:10.1175/1520-0442(2000)013〈2217:RTCSTC $\rangle 2.0 . C O ; 2$.

Notaro, M., Y. Wang, Z. Liu, R. Gallimore, and S. Levis, 2008: Combined statistical and dynamical assessment of simulated vegetation-rainfall during the mid-Holocene. Glob.Change Biol., 14 (2), 347 - 368, doi:10.1111/j.1365-2486.2007.01495.x.

Obata, A., 2007: Climate-carbon cycle model response to freshwater discharge into the North Atlantic. J. Climate, 20 (24), 5 962-5 976, doi:10.1175/2007JCLI1808.1.

Okumura, Y. and S. Xie, 2004: Interaction of the Atlantic equatorial cold tongue and the African monsoon. J. Climate, 17 (18), 3589 - 3 602, doi:10.1175/1520-0442(2004)017〈3589:IOTAEC〉 2.0.CO;2.

Opsteegh, J. D., R. J. Haarsma, F. M. Selten, and A. Kattenberg, 1998: ECBILT: A dynamic alternative to mixed boundary conditions in ocean models. Tellus, 50A (3), 348-367, doi:10. 1034/j.1600-0870.1998.t01-1-00007.x.

Overpeck, J., D. Anderson, S. Trumbore, and W. Prell, 1996: The southwest Indian Monsoon over the last 18000 years. Climate Dynamics, 12 (3), 213 - 225, doi:10.1007/BF00211619. 
Patricola, C. M. and K. H. Cook, 2008: Atmosphere/vegetation feedbacks: A mechanism for abrupt climate change over nothern Africa. J. Geophys. Res., 113, D18102, doi:10.1029/ 2007JD009608.

Peck, J. A., R. R. Green, T. Shanahan, J. W. King, J. T. Overpeck, and C. A. Scholz, 2004: A magnetic mineral record of Late Quaternary tropical climate variability from Lake Bosumtwi, Ghana. Palaeogeography, Palaeoclimatology, Palaeoecology, 215 (1-2), 37 - 57, doi:10.1016/j. palaeo.2004.08.003.

Peltier, W. R., 1994: Ice age paleotopography. Science, 265 (5169), 195-201, doi:10.1126/science. 265.5169 .195$.

Peltier, W. R., 2005: On the hemispheric origins of meltwater pulse 1A. Quat. Sci. Rev., 24, 1 6551671, doi:10.1016/j.quascirev.2004.06.023.

Peyron, O., D. Jolly, P. Braconnot, R. Bonnefille, J. Guiot, D. Wirrmann, and F. Chalie, 2006: Quantitative reconstructions of annual rainfall in Africa 6000 years ago: Model-data comparison. J. Geophys. Res., 111 (D24), doi:10.1029/2006JD007396.

Pope, V. D., M. L. Gallani, P. R. Rowntree, and R. A. Stratton, 2000: The impact of new physical parametrizations in the Hadley Centre climate model: HadAM3. Climate Dynamics, 16 (2-3), 123-146, doi:10.1007/s003820050009.

Prentice, I. C. and D. Jolly, 2000: Mid-Holocene and glacial-maximum vegetation geography of the northern continents and Africa. J. Biogeogr., 27 (3), 507 - 519, doi:10.1046/j.1365-2699. 2000.00425.x. 
Renssen, H., V. Brovkin, T. Fichefet, and H. Goosse, 2003: Holocene climate instability during the termination of the African Humid Period. Geophys. Res. Lett., 30 (4), 1061, doi:10.1029/ 2002 GL016155.

Renssen, H., V. Brovkin, T. Fichefet, and H. Goosse, 2006a: Simulation of the Holocene climate evolution in Northern Africa: The termination of the African Humid Period. Quat. Int., 150, 95 - 102, doi:10.1016/j.quaint.2005.01.001.

Renssen, H., E. Driesschaert, M. F. Loutre, and T. Fichefet, 2006b: On the importance of initial conditions for simulations of the Mid-Holocene climate. Clim. Past., 2 (2), 91 - 97.

Renssen, H., H. Goosse, and T. Fichefet, 2002: Modeling the effect of freshwater pulses on the early Holocene climate: The influence of high-frequency climate variability. Paleoceanography, 17 (2), 1020, doi:10.1029/2001PA000649.

Renssen, H., H. Goosse, T. Fichefet, V. Brovkin, E. Driesschaert, and F. Wolk, 2005: Simulating the Holocene climate evolution at northern high latitudes using a coupled atmosphere-sea iceocean-vegetation model. Clim. Dyn., 24 (1), 23 - 43, doi:10.1007/s00382-004-0485-y.

Richter, I. and S.-P. Xie, 2008: On the origin of equatorial Atlantic biases in coupled general circulation models. Climate Dynamics, 31 (5), 587-598, doi:10.1007/s00382-008-0364-z.

Rohling, E., R. Marsh, N. Wells, S. M., and N. Edwards, 2004: Similar meltwater contributions to glacial sea level changes from Antarctic and northern ice sheets. Nature, 430, $1016-1021$.

Severinghaus, J. P. and E. J. Brook, 1999: Abrupt climate change at the end of the last glacial period inferred from trapped air in polar ice. Science, 286 (5441), 930 - 934, doi:10.1126/science.286. 5441.930. 
Shanahan, T. M., et al., 2006: Paleoclimatic variations in West Africa from a record of late Pleistocene and Holocene lake level stands of Lake Bosumtwi, Ghana. Palaeogeography, Palaeoclimatology, Palaeoecology, 242 (3-4), 287-302, doi:10.1016/j.palaeo.2006.06.007.

Sirocko, F., D. Garbe-Schönberg, A. McIntyre, and B. Molfino, 1996: Teleconnections between the subtropical monsoons and high-latitude climates during the last deglaciation. Science, 272 (5261), 526-529, doi:10.1126/science.272.5261.526.

Sitch, S., et al., 2003: Evaluation of ecosystem dynamics, plant geography and terrestrial carbon cycling in the LPJ dynamic global vegetation model. Glob. Change Biol., 9, 161-185.

Smith, H. J., H. Fischer, M. Wahlen, D. Mastroianni, and B. Deck, 1999: Dual modes of the carbon cycle since the Last Glacial Maximum. Nature, 400 (6741), 248-250, doi:10.1038/22291.

Stouffer, R. J. et al., 2006: Investigating the causes of the response of the thermohaline circulation to past and future climate changes. J. Climate, $19(8), 1,365-1,387$, doi:10.1175/JCLI3689.1.

Strassmann, K., F. Joos, and G. Fischer, 2008: Simulating effects of land use changes on carbon fluxes: Past contributions to atmospheric $\mathrm{CO}_{2}$ increases and future commitments due to losses of terrestrial sink capacity. Tellus, 60B, 583-603, doi:10.1111/j.1600-0889.2008.00340.x.

Texier, D., et al., 1997: Quantifying the role of biosphere-atmosphere feedbacks in climate change: Coupled model simulations for 6000 years BP and comparison with palaeodata for northern Eurasia and northern Africa. Climate Dynamics, 13 (12), 865-881, doi:10.1007/ s003820050202.

Timm, O. and A. Timmermann, 2007: Simulation of the last 21,000 years using accelerated transient boundary conditions. J. Climate, 20 (17), 4377-4401, doi:10.1175/JCLI4237.1. 
Timmermann, A., S. J. Lorenz, S.-I. An, A. Clement, and S.-P. Xie, 2007: The effect of orbital forcing on the mean climate and variability of the tropical Pacific. J. Climate, 20 (16), 4 1474 159, doi:10.1175/JCLI4240.1.

Timmermann, A., O. Timm, L. Stott, and L. Menviel, 2009: The roles of $\mathrm{CO}_{2}$ and orbital forcing in driving southern hemispheric temperature variations during the last 21,000 years. J. Climate, 22 (7), 1 626-1 640, doi:10.1175/2008JCLI2161.1.

Tjallingii, R., M. Claussen, J.-B. W. Stuut, J. Fohlmeister, A. Jahn, T. Bickert, F. Lamy, and R. U., 2008: Coherent high- and low-latitude control of the northwest African hydrological balance. Nature Geosci., 1, 670-675, doi:10.1038/ngeo289.

Uppala, S. M. et al., 2005: The ERA-40 re-analysis. Quart. J. Roy. Meteor. Soc., 131, 2961-3 012, doi:10.1256/qj.04.176.

Wang, Y., M. Notaro, Z. Liu, R. Gallimore, S. Levis, and J. E. Kutzbach, 2008: Detecting vegetation-precipitation feedbacks in mid-Holocene North Africa from two climate models. Clim. Past, 4 (1), 59-67.

Wang, Y. J., H. Cheng, R. L. Edwards, Z. S. An, J. Y. Wu, C. C. Shen, and J. A. Dorale, 2001: A high-resolution absolute-dated Late Pleistocene monsoon record from Hulu cave, China. Science, 294 (5550), 2345 - 2 348, doi:10.1126/science.1064618.

Weldeab, S., D. Lea, R. Schneider, and N. Andersen, 2007: 155,000 years of West African monsoon and ocean thermal evolution. Science, 316 (5829), 1303 - 1307, doi:10.1126/science. 1140461. 
Xie, P. and P. A. Arkin, 1997: Global precipitation: A 17-year monthly analysis based on gauge observations, satellite estimates, and numerical model outputs. Bull. Amer. Meteor. Soc., 78, 2539-2 558, doi:10.1175/1520-0477(1997)078〈2539:GPAYMA $>2.0 . C O ; 2$.

Xue, Y. and J. Shukla, 1998: Model simulation of the influence of global SST anomalies on Sahel rainfall. Mon. Wea. Rev., 126 (11), 2782 - 2 792, doi:10.1175/1520-0493(1998)126〈2782: MSOTIO $\rangle 2.0 . \mathrm{CO} ; 2$.

Xue, Y. K. and J. Shukla, 1996: The influence of land surface properties on Sahel climate. Part II. afforestation. J. Climate, 9 (12), 3260 - 3275, doi:10.1175/1520-0442(1996)009/3260: TIOLSP $\rangle 2.0 . \mathrm{CO} ; 2$.

Yuan, D. X., et al., 2004: Timing, duration, and transitions of the last interglacial Asian Monsoon. Science, 304 (5670), 575 - 578, doi:10.1126/science.1091220.

Zeng, N., K. Hales, and D. Neelin, 2002: Nonlinear dynamics in a coupled vegetation-atmosphere system and implications for desert-forest gradient. J. Climate, 15 (23), 3474-3 487, doi:0.1175/ 1520-0442(2002)015〈3474:NDIACV $\rangle 2.0 . C O ; 2$.

Zeng, N., J. D. Neelin, K. M. Lau, and C. J. Tucker, 1999: Enhancement of interdecadal climate variability in the Sahel by vegetation interaction. Science, 286 (5444), 1537 - 1540.

Zhang, R. and T. L. Delworth, 2006: Impact of Atlantic multidecadal oscillations on India/Sahel rainfall and Atlantic hurricanes. Geophys. Res. Lett., 33, L17712, doi:10.1029/2006GL026267. 


\section{List of Tables}

1 Summary of the model simulations used in this study. Rows describe the model components (atmosphere-ocean, vegetation) and the coupling between atmosphere and vegetation: $\downarrow$ for atmosphere to vegetation and $\uparrow$ for vegetation to atmosphere. Modification refers to specific changes in the model compared with their standard versions. External forcing describes which transient forcing factors were prescribed during the simulations. See text for further details. 


\begin{tabular}{|c|c|c|c|c|c|c|c|c|c|c|}
\hline $\begin{array}{l}\text { Simulation } \\
\text { properties }\end{array}$ & LPJALL & LPJF190 & LPJF283 & $\overline{\text { ALL }}$ & NOALBFEEDB & ORBONLY & ICEONLY & CO2ONLY & ORBCO2 & CTR \\
\hline atmosphere-ocean & \multicolumn{3}{|c|}{ HadSM3 } & \multicolumn{7}{|c|}{ ECBilt-CLIO(V3) } \\
\hline vegetation & \multicolumn{3}{|c|}{ LPJ } & VECODE & $\begin{array}{c}\text { prescribed } \\
\text { (present day) }\end{array}$ & VECODE & $\begin{array}{c}\text { prescribed } \\
\text { (present day) }\end{array}$ & VECODE & $\begin{array}{c}\text { prescribed } \\
\text { (present day) }\end{array}$ & VECODE \\
\hline $\begin{array}{c}\text { coupling atm } \\
\downarrow \\
\text { vegetation }\end{array}$ & \multicolumn{3}{|c|}{$\begin{array}{l}\text { temp } \\
\text { precip } \\
\text { clouds }\end{array}$} & \multicolumn{7}{|c|}{$\begin{array}{l}\text { temp } \\
\text { precip }\end{array}$} \\
\hline $\begin{array}{c}\text { coupling atm } \\
\uparrow \\
\text { vegetation } \\
\end{array}$ & \multicolumn{3}{|c|}{ BIOME4 updated HadSM3 surface } & albedo & none & albedo & none & albedo & albedo & albedo \\
\hline modification & & $\begin{array}{l}\mathrm{CO}_{2} \text { fixed at } 190 \\
\text { ppmv in LPJ }\end{array}$ & $\begin{array}{l}\mathrm{CO}_{2} \text { fixed at } 283 \\
\text { ppmv in LPJ }\end{array}$ & \multicolumn{7}{|c|}{ increased $\mathrm{CO}_{2}$ sensitivity (Timm and Timmermann 2007) } \\
\hline hypothesis & $\mathrm{H} 3$, & $\mathrm{H} 3$ & $\mathrm{H} 3$ & $\mathrm{H} 1, \mathrm{H} 2, \mathrm{H} 3$ & $\mathrm{H} 2$ & $\mathrm{H} 1$ & H1 & (H1) & (H1) & \\
\hline external forcing & \multicolumn{3}{|c|}{ Orbital $(\mathrm{O})$, Greenhouse Gases $(\mathrm{G})$, Ice-sheets (I) } & $\mathrm{O}, \mathrm{G}, \mathrm{I}$ & $\mathrm{O}, \mathrm{G}, \mathrm{I}$ & $\mathrm{O}$ & $\mathrm{I}$ & $\mathrm{G}$ & $\mathrm{O}, \mathrm{G}$ & preindustrial \\
\hline
\end{tabular}

TABLE 1. Summary of the model simulations used in this study. Rows describe the model components (atmosphere-ocean, vegetation) and the coupling between atmosphere and vegetation: $\downarrow$ for atmosphere to vegetation and $\uparrow$ for vegetation to atmosphere. Modification refers to specific changes in the model compared with their standard versions. External forcing describes which transient forcing factors were prescribed during the simulations. See text for further details. 


\section{List of Figures}

1 Schematic view graph of forcing factors and climate-vegetation interactions involved in determining the onset and termination of the African Humid Period. Potential thresholds exist for the precipitation minus evaporation (P-E) balance over North Africa and the vegetation as well as within the atmosphere through shifts in the ITCZ. This study analyzes the role of the feedback from the vegetation to precipitation and the role of individual forcings for the precipitation-vegetation state in the North African monsoon region. Oceanic feedbacks and the role of the Atlantic meridional overturning circulation (AMOC) are not explicitly analyzed with specific numerical experiments in this study.

2 Mean annual cycle of the precipitation averaged over $15^{\circ} \mathrm{W}-15^{\circ} \mathrm{E}$ presented in a Hovmœller plot as a function of latitude. The preindustrial control simulation with LOVECLIM (CTR) is shown in (a). The average monthly mean values were obtained from the last hundred years of the 1000-year-long simulation. In (b) the monthly mean CMAP (Xie and Arkin 1997) climatology averaged over the years 1979-2004 is shown. (c) same as (a) but for the $2 \mathrm{~m}$ air temperature as anomalies with respect to the annual mean; (d) $2 \mathrm{~m}$ air temperatures annual mean cycle obtained from ERA-40 (Uppala et al. 2005) 1959-2000. 
3 Mean annual cycle of the meridional wind on the equator (a) in the $800 \mathrm{hPa}$ level of the preindustrial control simulation. In (b) the monthly mean ERA-40 reanalysis (Uppala et al. 2005) climatology ( $850 \mathrm{hPa}$ level) averaged over the years 19592000 is shown. Contour interval is $1 \mathrm{~m} \mathrm{~s}^{-1}$. Shaded areas highlight southerly winds.

4 Prescribed boundary conditions (forcing) for the transient simulations with LOVECLIM: June insolation at $20^{\circ} \mathrm{N}$ (Berger 1978) (dashed line), atmospheric $\mathrm{CO}_{2}$ concentration (Indermühle et al. 1999; Smith et al. 1999) (gray), and Northern Hemisphere ice volume anomalies (after Peltier 1994) (black line). Note that an accelerated forcing (factor 10) was applied (see Timm and Timmermann 2007).

5 Time series of (a) $2 \mathrm{~m}$ air temperature, (b) annual precipitation, and (c) terrestrial carbon over North Africa $\left(15^{\circ} \mathrm{N}-30^{\circ} \mathrm{N} / 15^{\circ} \mathrm{W}-35^{\circ} \mathrm{E}\right)$. ALL (light green), NOALBFEEDB (blue), ORBONLY (orange), ORBCO2 (red), CO2ONLY (gray), ICEONLY (cyan), LPJALL (dark green). Offsets between ALL and NOALBFEEDB and ICEONLY at $21 \mathrm{ka} \mathrm{B.P.} \mathrm{are} \mathrm{due} \mathrm{to} \mathrm{the} \mathrm{prescribed} \mathrm{present-day} \mathrm{albedo} \mathrm{in} \mathrm{NOALBFEEDB} \mathrm{and}$ ICEONLY. Note that temperatures and the precipitation of LPJALL are the prescribed atmospheric forcings for the vegetation derived with HadSM3. Right yaxis in (b) and (c) for LPJALL.

$6200 \mathrm{hPa}$ velocity potential $\chi_{200}$ in ALL (black contours, units $10^{-5} \mathrm{~m}^{2} \mathrm{~s}^{-1}$ ) at $11 \mathrm{ka}$ B.P. Shaded colors show the difference between $\chi_{200}$ of ALL minus ORBONLY ( units $10^{-5} \mathrm{~m}^{2} \mathrm{~s}^{-1}$ ). Positive (negative) values indicate convergent (divergent) upper-level winds. 
7 Effective rate of change (12-11 ka B.P. minus 15-14 ka B.P.) in (a) 2 m annual mean temperature, (b) annual mean precipitation, (c) terrestrial carbon stock over North Africa during the onset of the AHP: Simulation ALL (NOALBFEEDB) with all forcings active and with (without) vegetation-albedo-precipitation feedback; ICEONLY only time-dependent ice-sheets; ORBCO2 with orbital and $\mathrm{CO}_{2}$ forcing; ORBONLY only orbital forcing; CO2ONLY only $\mathrm{CO}_{2}$ forcing. See Tab. 1 for more details on the simulations. Note that larger carbon stock response in NOALBFEEDB compared to ALL is due to the selected present-day albedo in NOALBFEEDB.

8 Simulated plant fraction coverage (in percent) during the maximum of the African Humid Period 9-8 ka B.P. in (a) LOVECLIM with vegetation-albedo-precipitation feedback (ALL), (b) LOVECLIM without vegetation-albedo-precipitation feedback (NOALBFEEDB) and (c) the period 12-10 ka B.P. in LPJALL. The preindustrial vegetation cover of the CTR simulation cover is shown in (d).

9 Precipitation (black contours, [mm/day]), moisture flux (gray vectors , $[\mathrm{g} / \mathrm{kg} \mathrm{m} / \mathrm{s}]$ ) and moisture flux convergence (divergence) $\left[10^{5} \mathrm{~g} /(\mathrm{kg} \mathrm{s})\right]$ in blue (red) shading during the boreal summer season (June-September) (9-8 ka B.P.):(a) in the LOVECLIM simulation without vegetation-albedo-precipitation feedback (NOALBFEEDB), (b) difference between LOVECLIM simulation with and without vegetation-albedo feedback (ALL - NOALBFEEDB). In (b) blue colors mark regions of more moisture convergence and increased precipitation (contours) with the albedo-vegetationprecipitation feedback active. Note that the eddy moisture transport is neglected in this analysis. 
10 Scatter diagram showing the terrestrial carbon stock in relation to the annual precipitation over North Africa $\left(15^{\circ} \mathrm{N}-30^{\circ} \mathrm{N} / 15^{\circ} \mathrm{W}-35^{\circ} \mathrm{E}\right)$. (a) LPJALL (colored circles) and two sensitivity experiments. Experiment LPJF190 (blue line) and LPJF283 (red line) are similar to LPJALL but with constant atmospheric $\mathrm{CO}_{2}$ concentrations of 190 ppmv and 283 ppmv in the parametrization of net primary production, respectively; (b) same scatter plot for ALL. Blue, green and black circles mark the time before, during and after the AHP in the simulations: in (a) 21-13 ka B.P., 13-7 ka B.P., 7-0 ka B.P.; in (b) 21-12 ka B.P., 12-8 ka B.P., 8-0 ka B.P.

11 Time series of the three monsoon proxy records from (a) terrigenous percent from OPD108_658C (deMenocal et al. 2000), (b) SSS reconstruction from MD03-2707 (Weldeab et al. 2007), and (c) organic percent from Lake Bosumtwi (Peck et al. 2004; Shanahan et al. 2006). The scatter plot in (d), (e) and (f) show the proxy plotted as function of the June insolation at $20^{\circ} \mathrm{N}$ (Berger 1978). The colors mark the clusters associated with the LGM (21-17 ka B.P., blue), the AHP (12-6 ka B.P., green), the late Holocene (0-6 ka B.P.,black) and the Younger Dryas zone (1214.5 ka B.P., cyan). Note that these intervals were optimized to visually distinguish the clusters for ODP108_658C. 


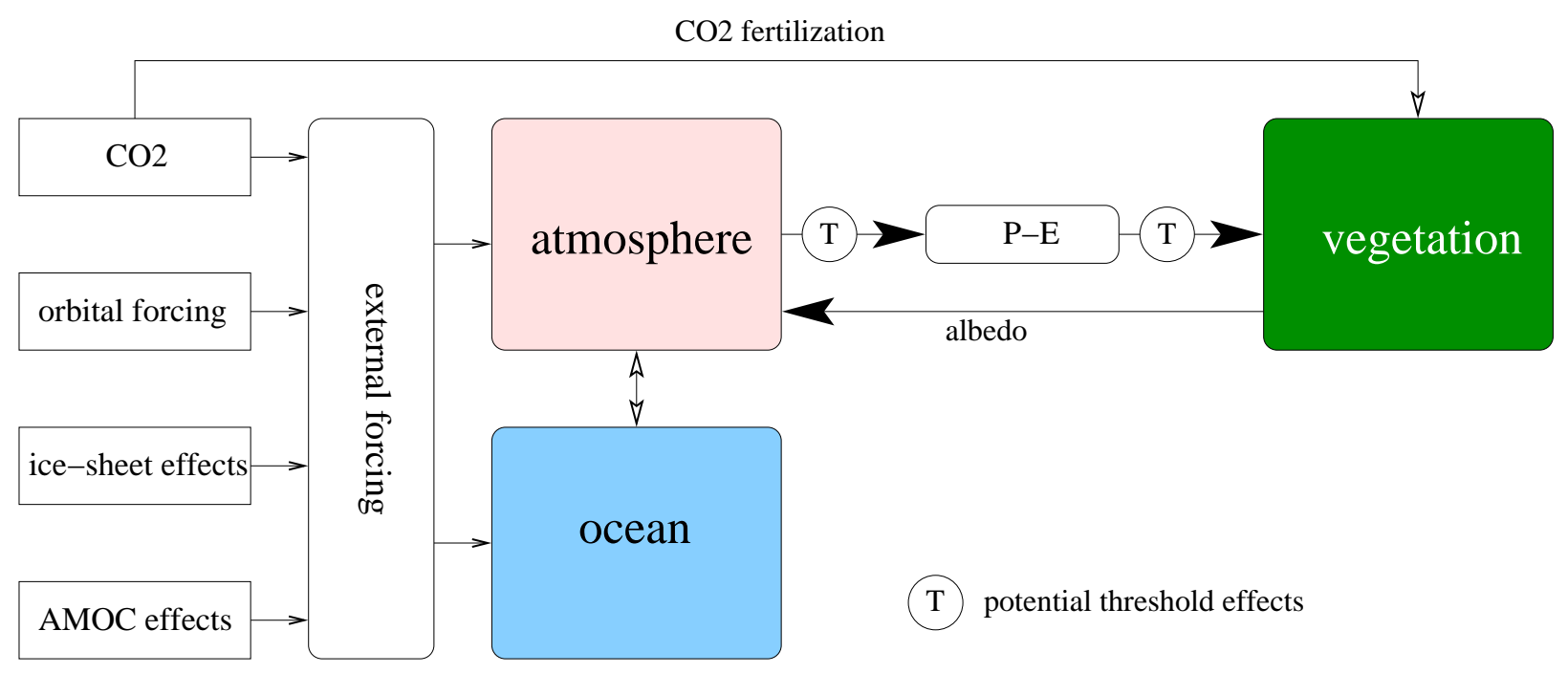

FIG. 1. Schematic view graph of forcing factors and climate-vegetation interactions involved in determining the onset and termination of the African Humid Period. Potential thresholds exist for the precipitation minus evaporation (P-E) balance over North Africa and the vegetation as well as within the atmosphere through shifts in the ITCZ. This study analyzes the role of the feedback from the vegetation to precipitation and the role of individual forcings for the precipitation-vegetation state in the North African monsoon region. Oceanic feedbacks and the role of the Atlantic meridional overturning circulation (AMOC) are not explicitly analyzed with specific numerical experiments in this study. 

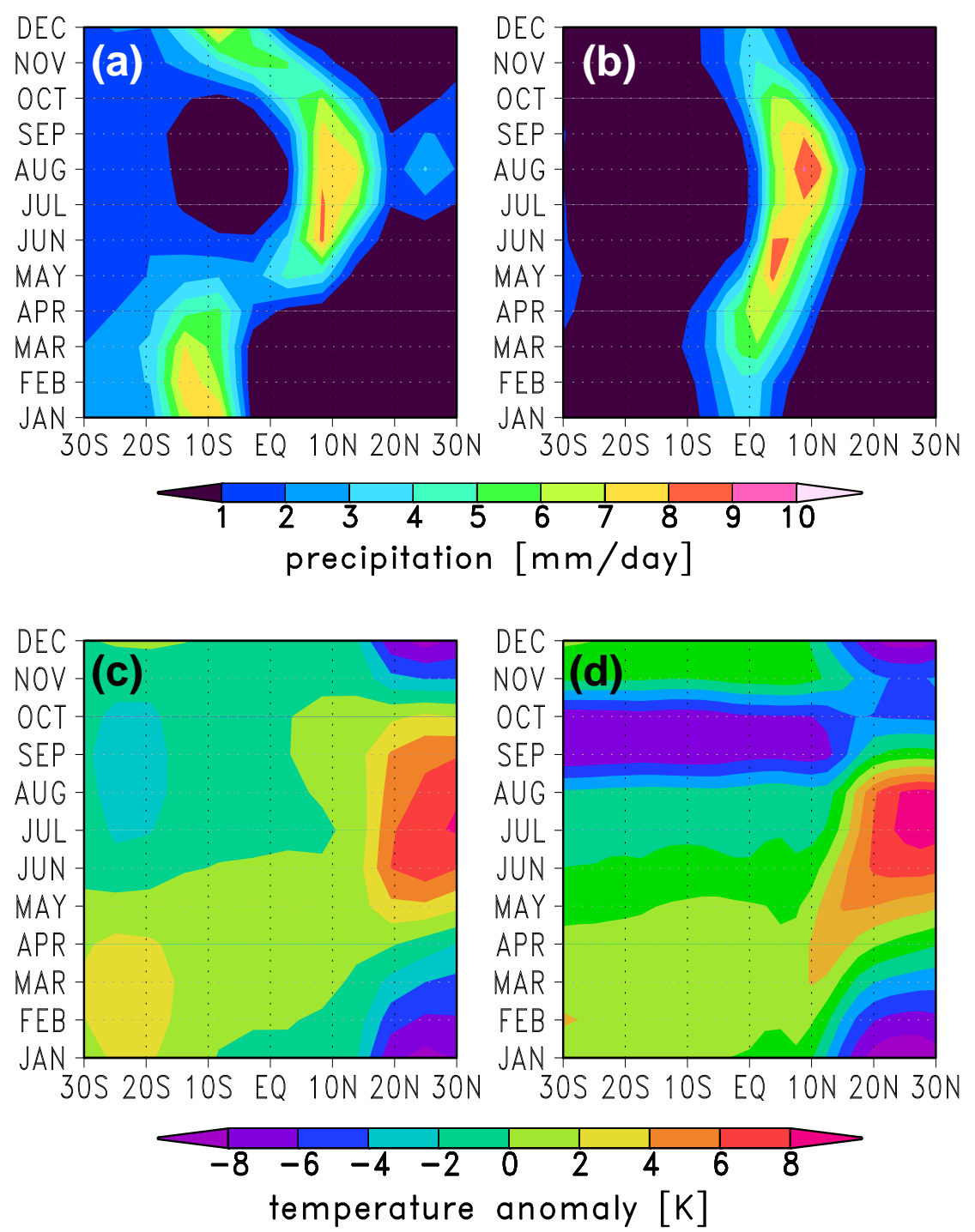

FIG. 2. Mean annual cycle of the precipitation averaged over $15^{\circ} \mathrm{W}-15^{\circ} \mathrm{E}$ presented in a Hovmœller plot as a function of latitude. The preindustrial control simulation with LOVECLIM (CTR) is shown in (a). The average monthly mean values were obtained from the last hundred years of the 1000-year-long simulation. In (b) the monthly mean CMAP (Xie and Arkin 1997) climatology averaged over the years 1979-2004 is shown. (c) same as (a) but for the $2 \mathrm{~m}$ air temperature as anomalies with respect to the annual mean; (d) $2 \mathrm{~m}$ air temperatures annual mean cycle obtained from ERA-40 (Uppala et al. 2005) 1959-2000. 

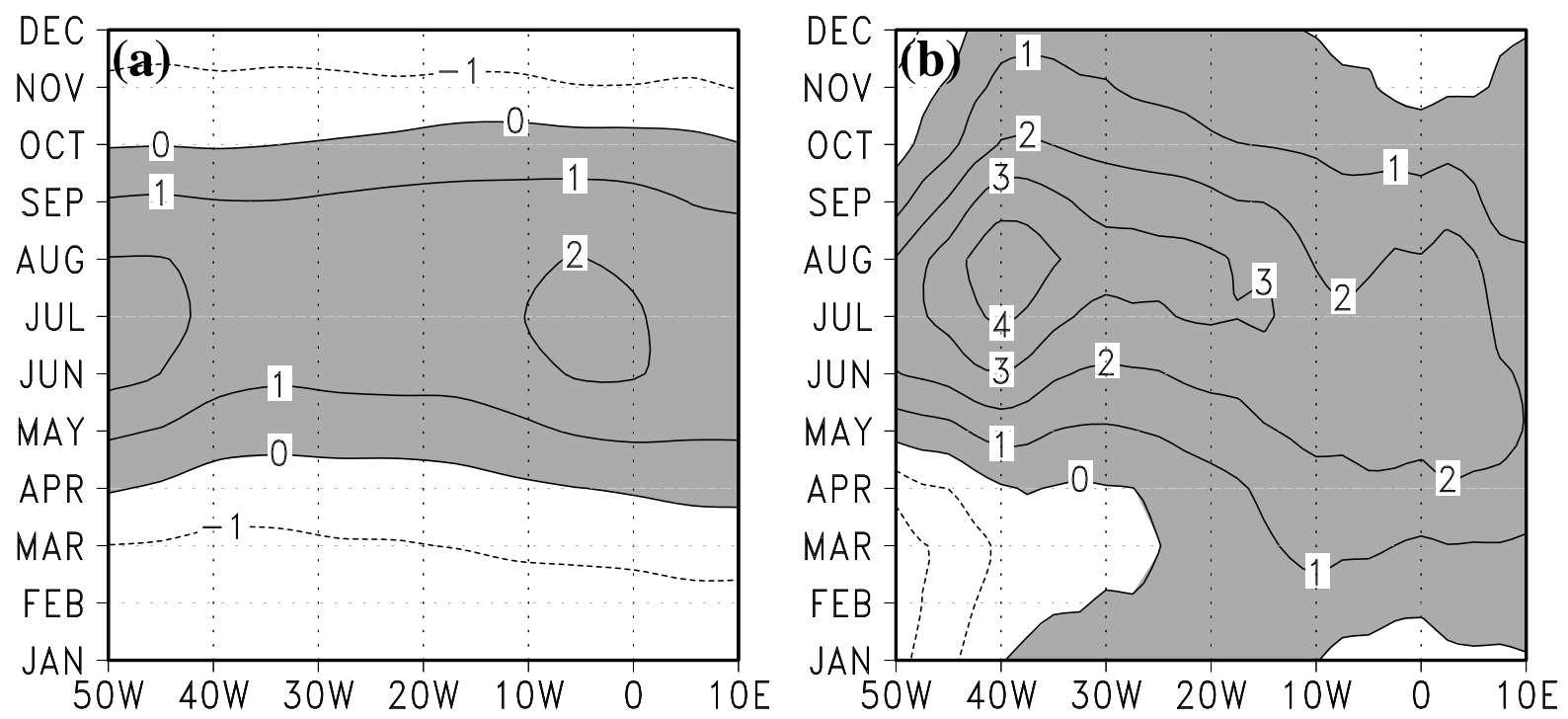

FIG. 3. Mean annual cycle of the meridional wind on the equator (a) in the $800 \mathrm{hPa}$ level of the preindustrial control simulation. In (b) the monthly mean ERA-40 reanalysis (Uppala et al. 2005) climatology ( $850 \mathrm{hPa}$ level) averaged over the years 1959-2000 is shown. Contour interval is $1 \mathrm{~m} \mathrm{~s}^{-1}$. Shaded areas highlight southerly winds. 


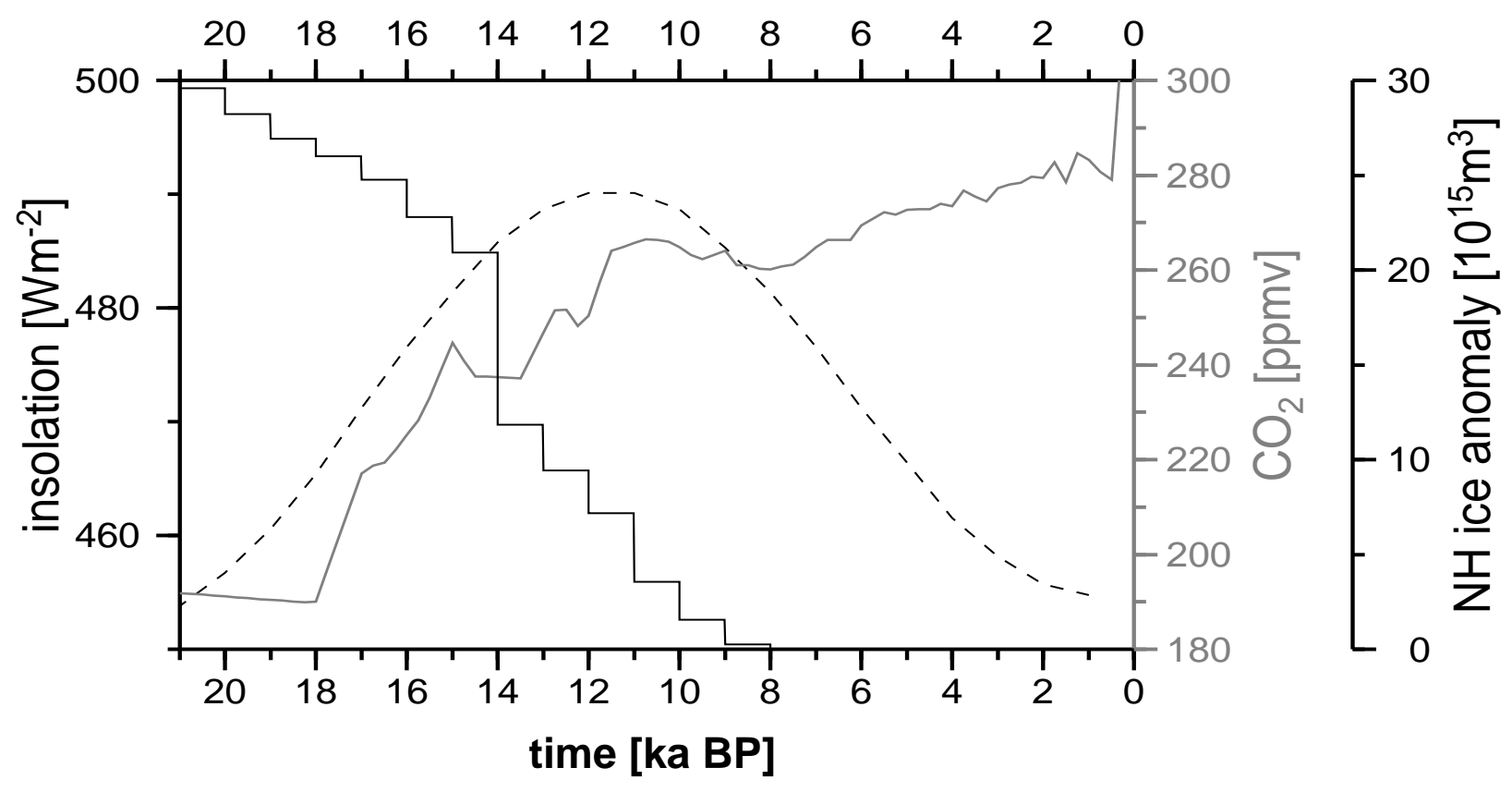

FIG. 4. Prescribed boundary conditions (forcing) for the transient simulations with LOVECLIM: June insolation at $20^{\circ} \mathrm{N}$ (Berger 1978) (dashed line), atmospheric $\mathrm{CO}_{2}$ concentration (Indermühle et al. 1999; Smith et al. 1999) (gray), and Northern Hemisphere ice volume anomalies (after Peltier 1994) (black line). Note that an accelerated forcing (factor 10) was applied (see Timm and Timmermann 2007). 

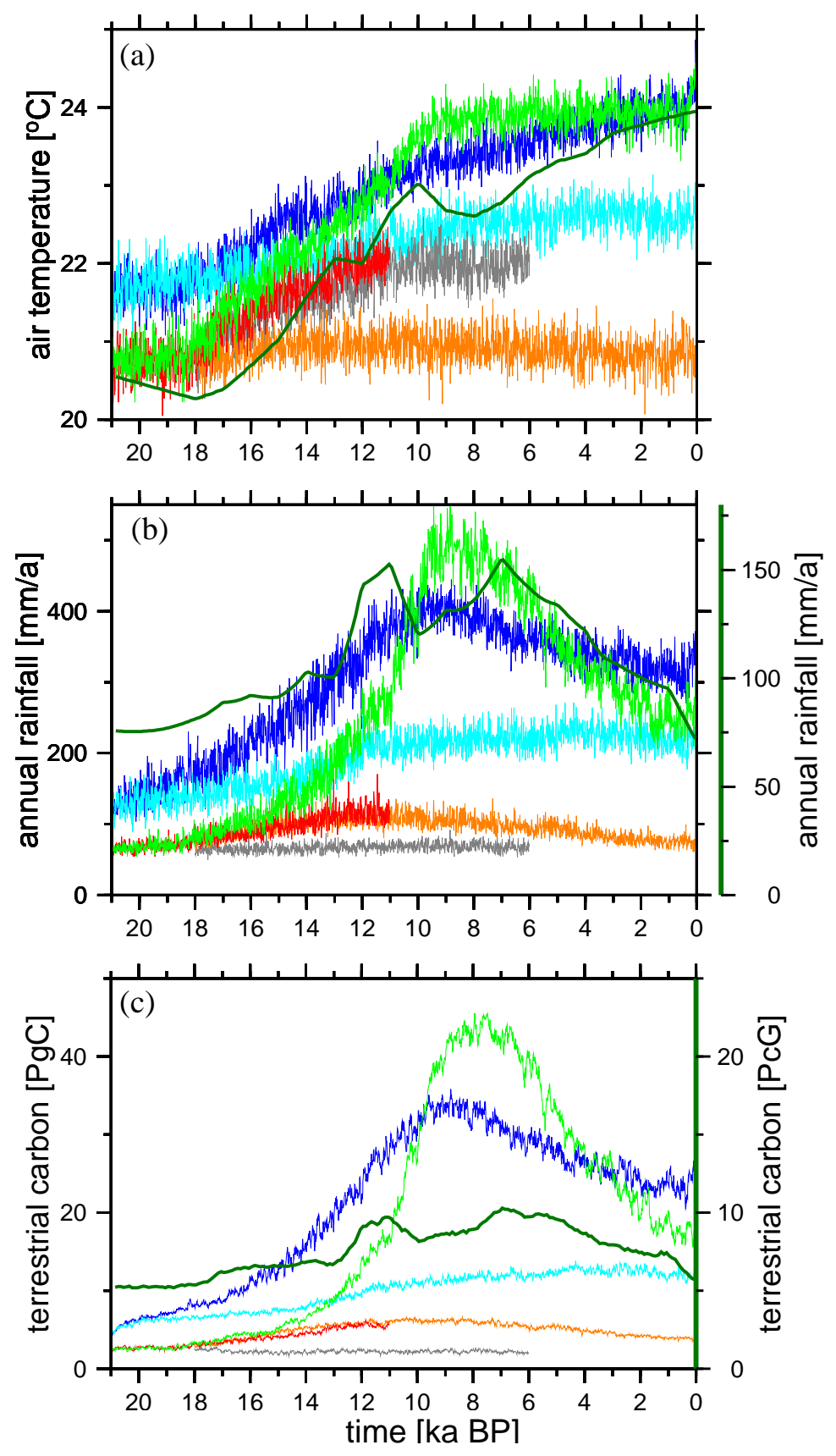

FIG. 5. Time series of (a) $2 \mathrm{~m}$ air temperature, (b) annual precipitation, and (c) terrestrial carbon over North Africa $\left(15^{\circ} \mathrm{N}-30^{\circ} \mathrm{N} / 15^{\circ} \mathrm{W}-35^{\circ} \mathrm{E}\right)$. ALL (light green), NOALBFEEDB (blue), ORBONLY (orange), ORBCO2 (red), CO2ONLY (gray), ICEONLY (cyan), LPJALL (dark green). Offsets between ALL and NOALBFEEDB and ICEONLY at $21 \mathrm{ka}$ B.P. are due to the prescribed present-day albedo in NOALBFEEDB and ICEONLY. Note that temperatures and the precipitation of LPJALL are the prescribed atmospheric forcings for the vegetation derived with HadSM3. Right y-axis in (b) and (c) for LPJALL. 

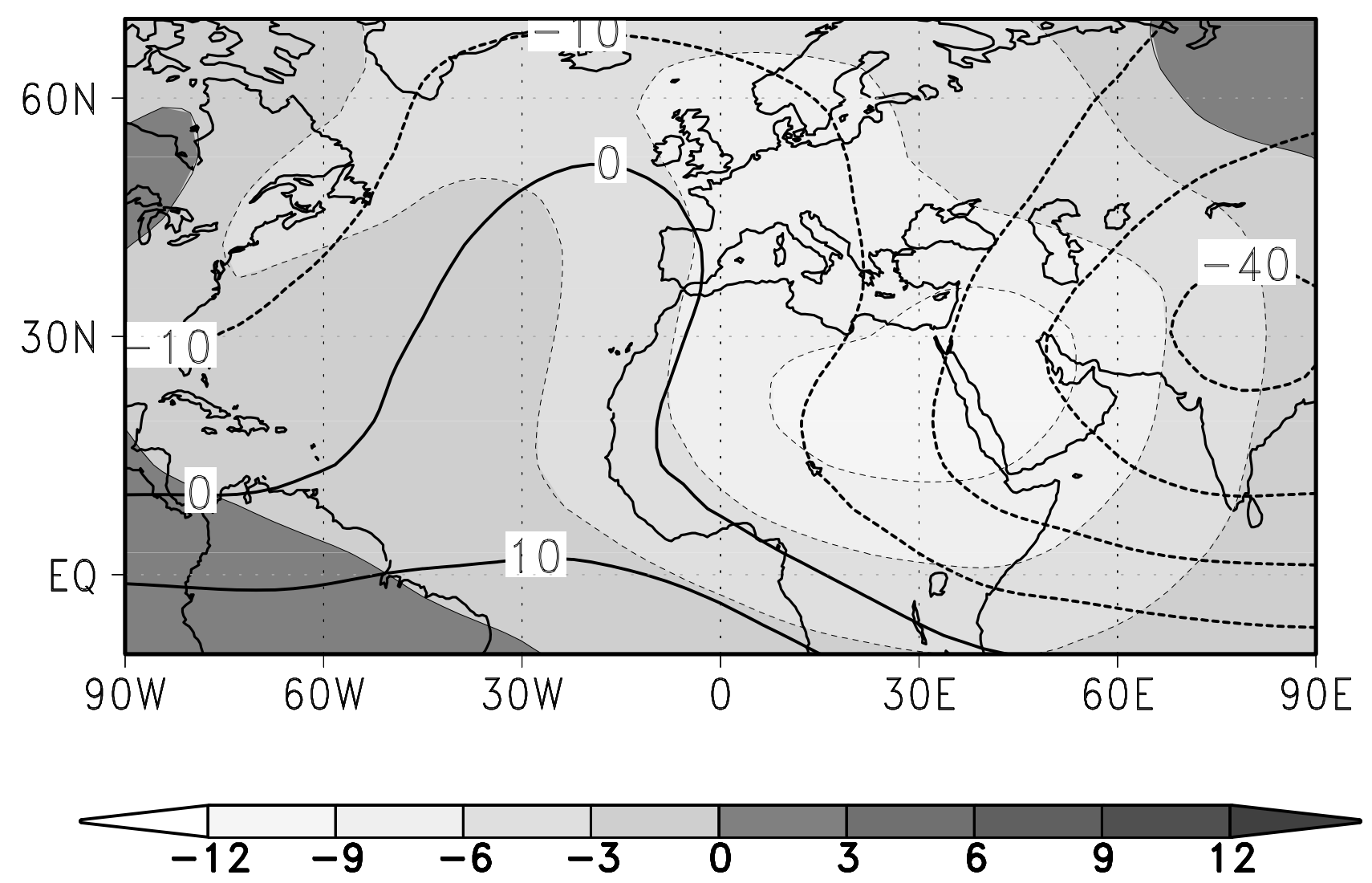

FIG. 6. $200 \mathrm{hPa}$ velocity potential $\chi_{200}$ in ALL (black contours, units $10^{-5} \mathrm{~m}^{2} \mathrm{~s}^{-1}$ ) at $11 \mathrm{ka}$ B.P. Shaded colors show the difference between $\chi_{200}$ of ALL minus ORBONLY ( units $10^{-5} \mathrm{~m}^{2} \mathrm{~s}^{-1}$ ). Positive (negative) values indicate convergent (divergent) upper-level winds. 


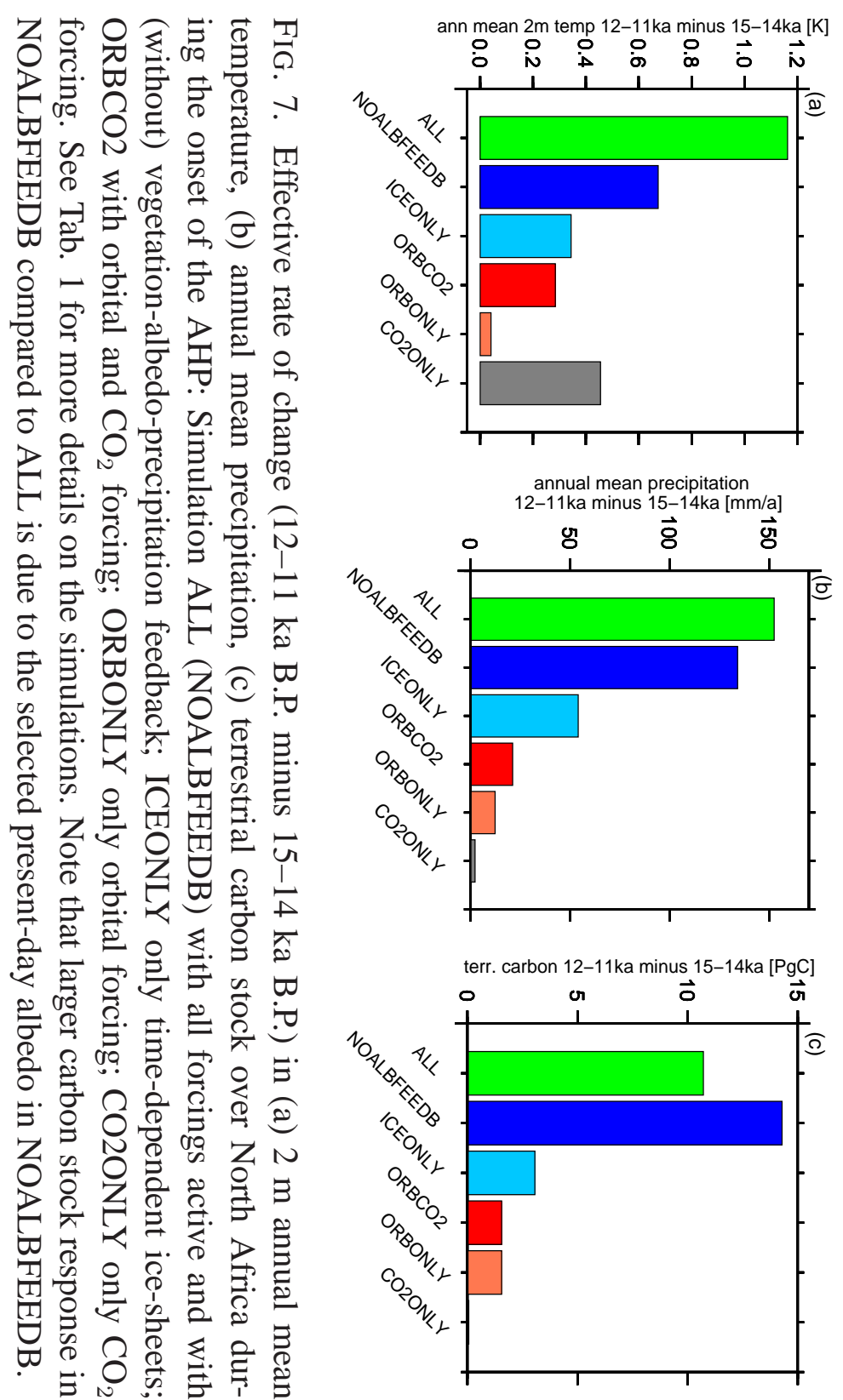



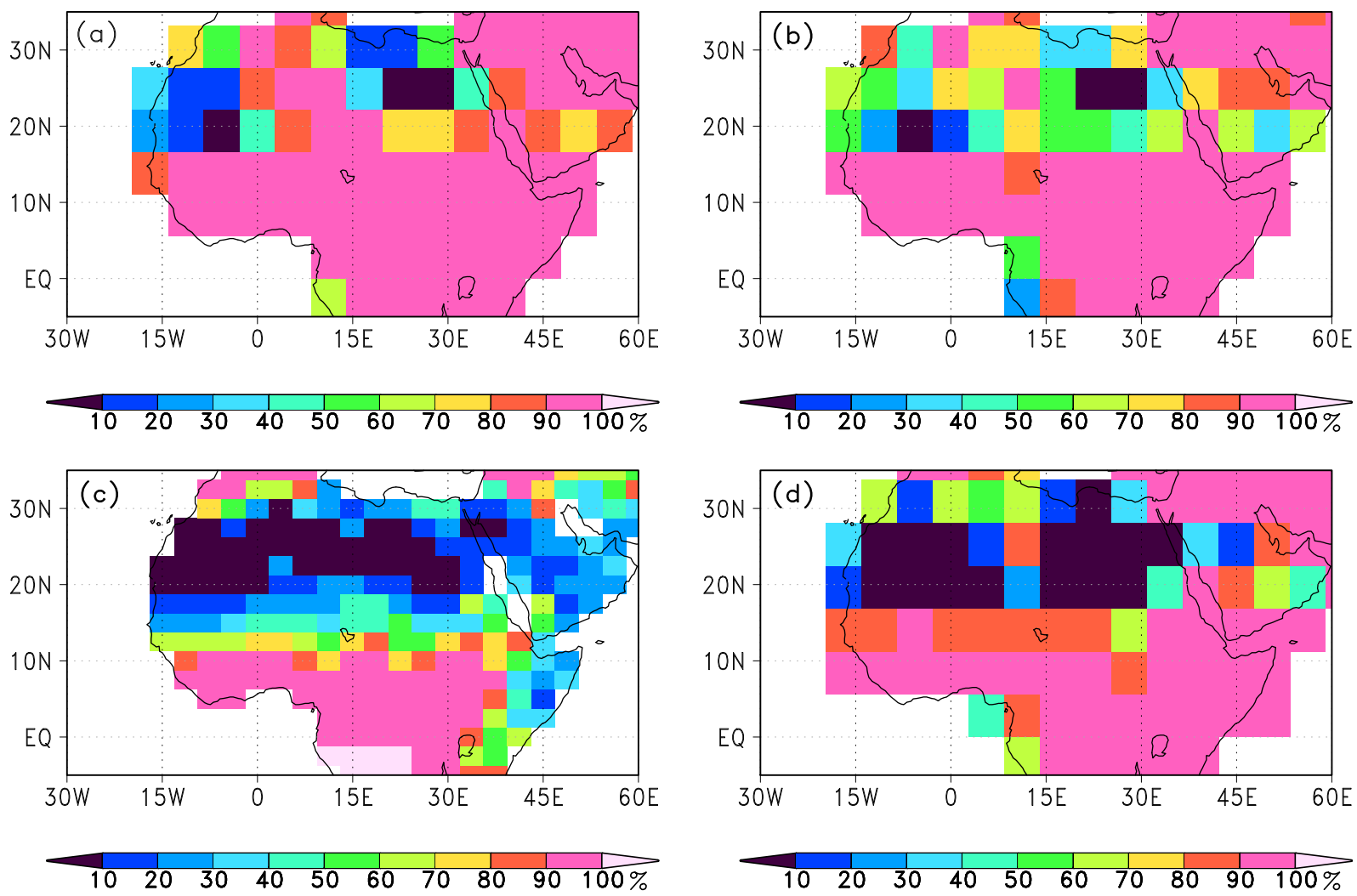

FIG. 8. Simulated plant fraction coverage (in percent) during the maximum of the African Humid Period 9-8 ka B.P. in (a) LOVECLIM with vegetation-albedo-precipitation feedback (ALL), (b) LOVECLIM without vegetation-albedo-precipitation feedback (NOALBFEEDB) and (c) the period 12-10 ka B.P. in LPJALL. The preindustrial vegetation cover of the CTR simulation cover is shown in (d). 

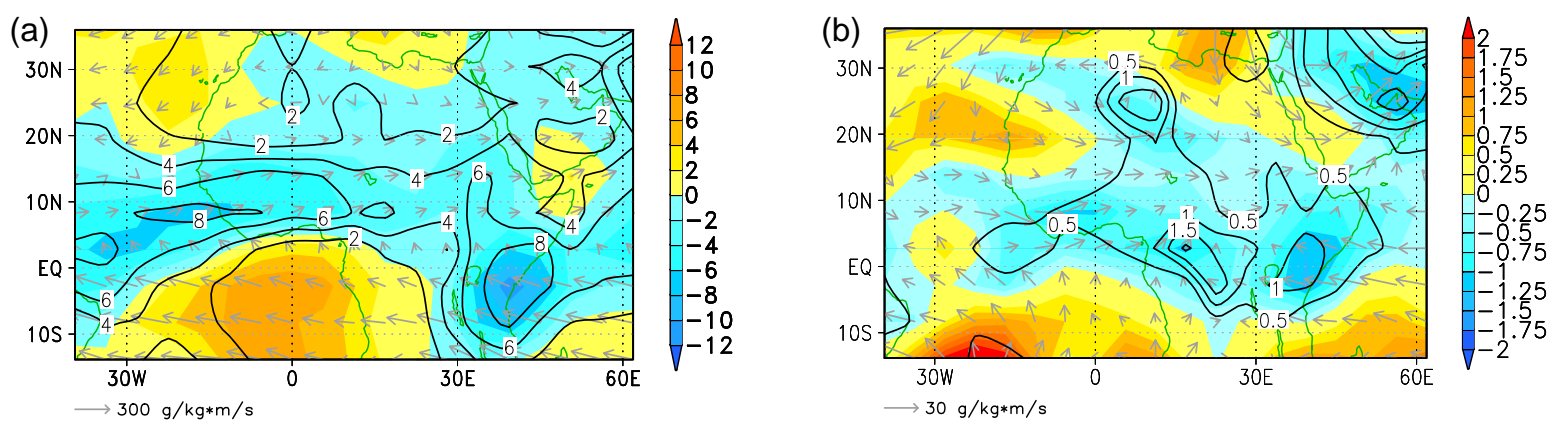

FIG. 9. Precipitation (black contours, [mm/day]), moisture flux (gray vectors , $[\mathrm{g} / \mathrm{kg} \mathrm{m} / \mathrm{s}]$ ) and moisture flux convergence (divergence) $\left[10^{5} \mathrm{~g} /(\mathrm{kg} \mathrm{s})\right]$ in blue (red) shading during the boreal summer season (June-September) (9-8 ka B.P.):(a) in the LOVECLIM simulation without vegetationalbedo-precipitation feedback (NOALBFEEDB), (b) difference between LOVECLIM simulation with and without vegetation-albedo feedback (ALL - NOALBFEEDB). In (b) blue colors mark regions of more moisture convergence and increased precipitation (contours) with the albedovegetation-precipitation feedback active. Note that the eddy moisture transport is neglected in this analysis. 

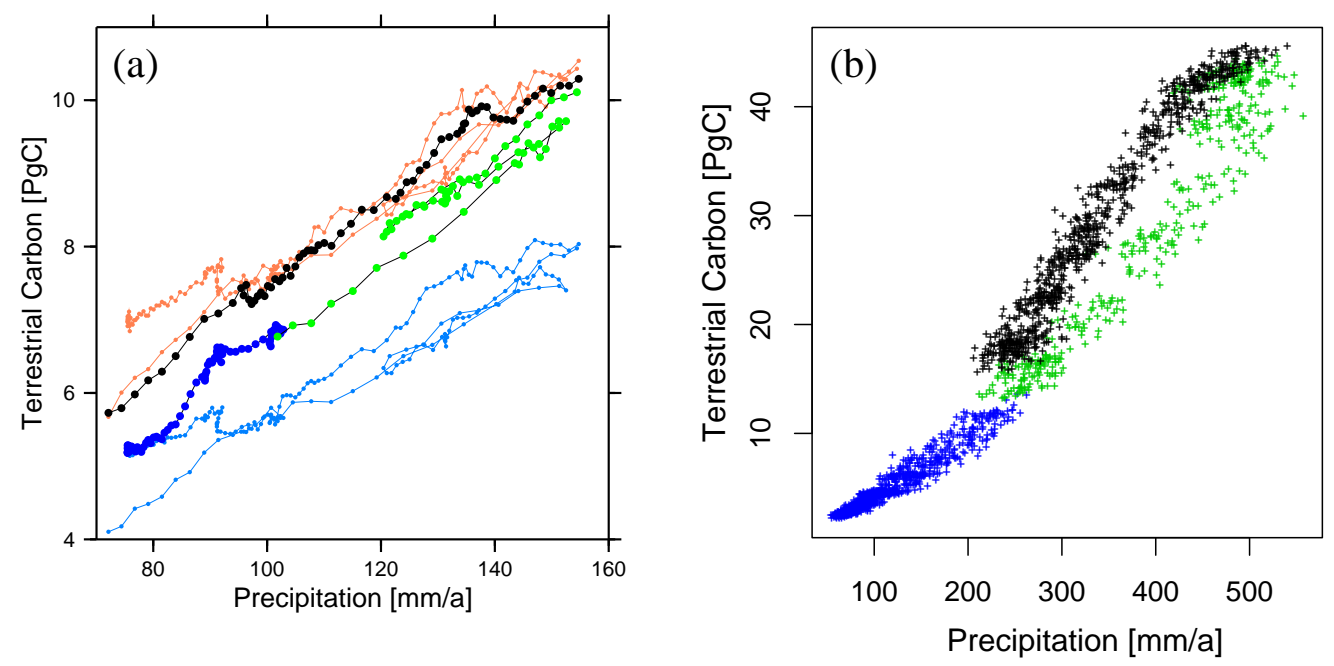

FIG. 10. Scatter diagram showing the terrestrial carbon stock in relation to the annual precipitation over North Africa $\left(15^{\circ} \mathrm{N}-30^{\circ} \mathrm{N} / 15^{\circ} \mathrm{W}-35^{\circ} \mathrm{E}\right)$. (a) LPJALL (colored circles) and two sensitivity experiments. Experiment LPJF190 (blue line) and LPJF283 (red line) are similar to LPJALL but with constant atmospheric $\mathrm{CO}_{2}$ concentrations of $190 \mathrm{ppmv}$ and $283 \mathrm{ppmv}$ in the parametrization of net primary production, respectively; (b) same scatter plot for ALL. Blue, green and black circles mark the time before, during and after the AHP in the simulations: in (a) 21-13 ka B.P., 13-7 ka B.P., 7-0 ka B.P.; in (b) 21-12 ka B.P., 12-8 ka B.P., 8-0 ka B.P. 
(a)

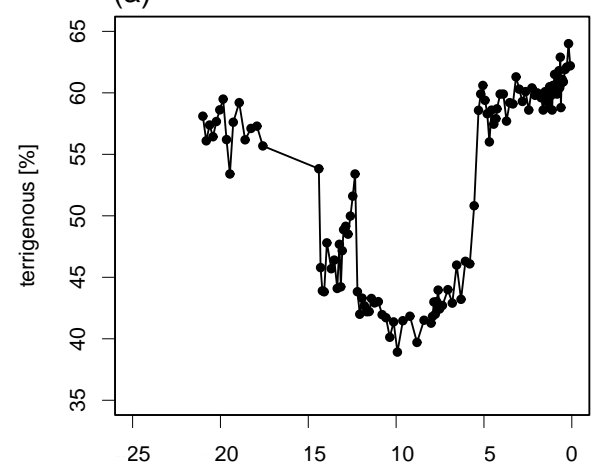

(b)

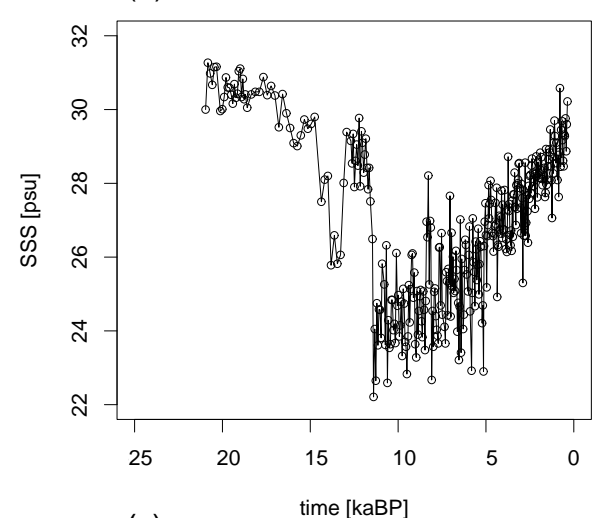

(c)

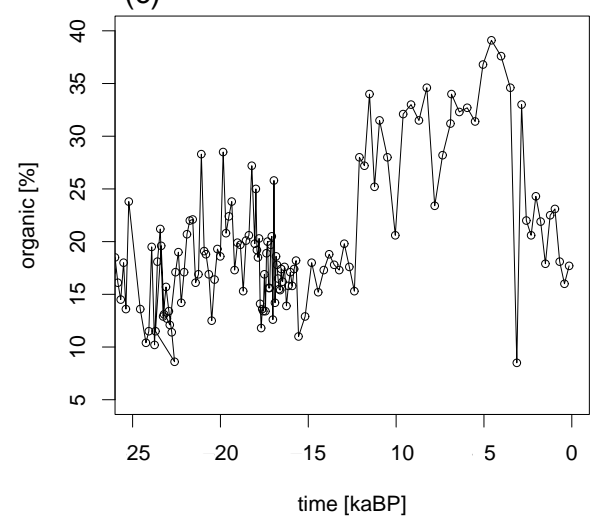

(d)

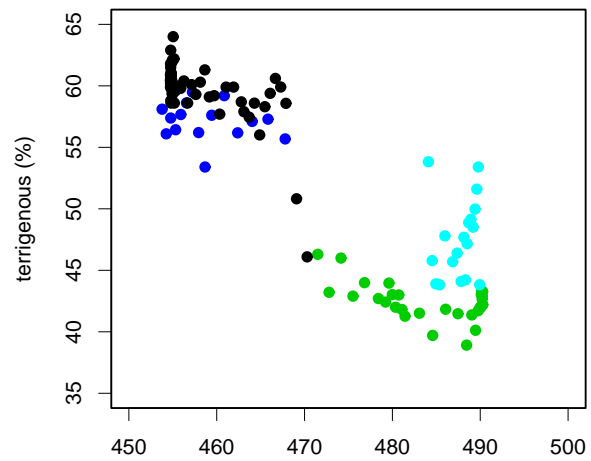

(e) $20 \mathrm{~N}$ June insolation $\left[\mathrm{W} / \mathrm{m}^{\wedge} 2\right]$

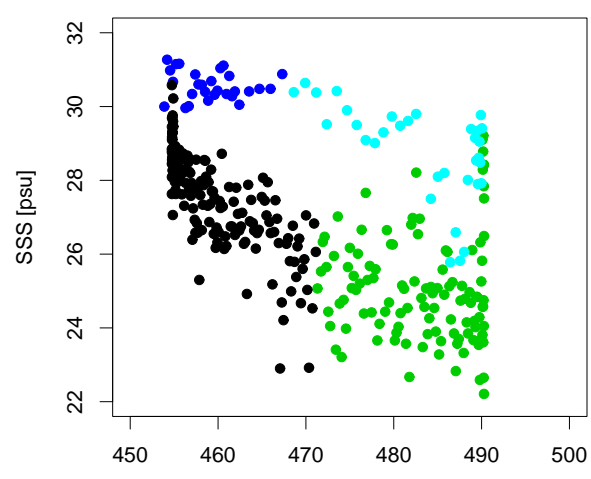

(f) $\quad 20 \mathrm{~N}$ June insolation $\left[\mathrm{W} / \mathrm{m}^{\wedge} 2\right]$

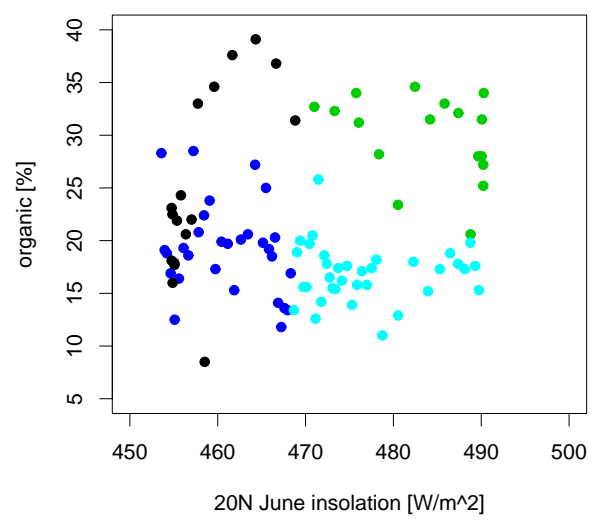

FIG. 11. Time series of the three monsoon proxy records from (a) terrigenous percent from OPD108_658C (deMenocal et al. 2000), (b) SSS reconstruction from MD03-2707 (Weldeab et al. 2007), and (c) organic percent from Lake Bosumtwi (Peck et al. 2004; Shanahan et al. 2006). The scatter plot in (d), (e) and (f) show the proxy plotted as function of the June insolation at $20^{\circ} \mathrm{N}$ (Berger 1978). The colors mark the clusters associated with the LGM (21-17 ka B.P., blue), the AHP (12-6 ka B.P., green), the late Holocene (0-6 ka B.P.,black) and the Younger Dryas zone (12$14.5 \mathrm{ka}$ B.P., cyan). Note that these intervals were optimized to visually distinguish the clusters for ODP108_658C. 